\title{
Consensus on Medical Nutrition Therapy for Diabesity (CoMeND) in Adults: A South Asian Perspective
}

This article was published in the following Dove Press journal: Diabetes, Metabolic Syndrome and Obesity: Targets and Therapy

Nitin Kapoor, (D) ${ }^{1,2}$ Rakesh Sahay, ${ }^{3}$ Sanjay Kalra, ${ }^{4}$ Sarita Bajaj, ${ }^{5}$ Arundhati Dasgupta, ${ }^{6}$ Dina Shrestha, ${ }^{7}$ Guru Dhakal, ${ }^{8}$ Mangesh Tiwaskar, (iD) Manisha Sahay, (iD ${ }^{10}$ Noel Somasundaram, " Ravinder Reddy, ${ }^{12}$ Saptarshi Bhattacharya, ${ }^{13}$ Vijaya Bhaskar Reddy, ${ }^{14}$ Vijay Viswanathan, ${ }^{15}$ Dharini Krishnan, ${ }^{16}$ Manash Baruah, ${ }^{17}$ A K Das ${ }^{18}$

'Department of Endocrinology, Christian Medical College, Vellore, Tamil Nadu, India; ${ }^{2}$ Non

Communicable Disease Unit, The Nossal Institute for Global Health, Melbourne School of Population and Global Health, University of Melbourne, Melbourne, Victoria, Australia; ${ }^{3}$ Department of Endocrinology, Osmania MedicalA30 College, Hyderabad, Telangana, India; ${ }^{4}$ Department of Endocrinology, Bharti Hospital, Karnal, Haryana, India; ${ }^{5}$ Department of Medicine, Moti Lal Nehru Medical College, Allahabad, Uttar Pradesh, India; ${ }^{6}$ Department of Endocrinology, Rudraksh

Superspecialty Hospital, Siliguri, West Bengal, India;

${ }^{7}$ Department of Endocrinology, Hospital for

Advanced Medicine and Surgery (HAMS),

Kathmandu, Nepal; ${ }^{8}$ Department of Medicine

Khesar Gyalpo University of Medical Sciences,

Thimphu, Bhutan; ${ }^{\circ}$ Department of Diabetology,

Shilpa Medical Research Centre, Mumbai,

Maharashtra, India; ${ }^{10}$ Department of Nephrology,

Osmania Medical College and Osmania General

Hospital, Hyderabad, Telangana, India;

"Department of Endocrinology, National Hospital of Sri Lanka, Colombo, Sri Lanka; ${ }^{2}$ Department of Gastroenterology, CARE Super Specialty Hospital

\& Transplant Centre, Hyderabad, Telangana, India;

${ }^{13}$ Department of Endocrinology, Max

Superspeciality Hospital, Delhi, India;

${ }^{14}$ Department of Endocrinology, Government

General Hospital, Pondicherry, India;

${ }^{15}$ Department of Medicine, M.V. Hospital for

Diabetes \& Prof M Viswanathan Diabetes Research

Centre, Chennai, Tamil Nadu, India; ${ }^{16}$ Department

of Food, Nutrition and Dietetics, Laksha Hospitals,

Chennai, Tamil Nadu, India; ${ }^{17}$ Department of

Endocrinology, Excel Care Hospitals, Guwahati,

Assam, India; ${ }^{18}$ Department of Medicine, JIPMER,

Puducherry, India

Correspondence: Sanjay Kalra

Bharti Hospital, Kunjpura Road, Model Town,

Near State Bank of India, Sector 12, Karnal,

Haryana, 132001

Tel +9/ 9896048555

Email bridekn!@gmail.com

\begin{abstract}
Diabetes and obesity are both increasing at a fast pace and giving rise to a new epidemic called diabesity. Lifestyle interventions including diet play a major role in the treatment of diabetes, obesity and diabesity. There are many guidelines on dietary management of diabetes or obesity globally and also from South Asia. However, there are no global or South Asian guidelines on the non-pharmacological management of diabesity. South Asia differs from the rest of the world as South Asians have different phenotype, cooking practices, food resources and exposure, medical nutrition therapy (MNT) practices, and availability of trained specialists. Therefore, South Asia needs its own guidelines for nonpharmacological management of diabesity in adults. The aim of the Consensus on Medical Nutrition Therapy for Diabesity (CoMeND) in Adults: A South Asian Perspective is to recommend therapeutic and preventive MNT in the South-Asians with diabesity.
\end{abstract}

Keywords: diabesity guidelines South Asia, medical nutrition therapy South Asia, nutrition therapy for obesity, nutrition therapy for diabetes, diabetes, obesity and diabesity

\section{Introduction}

Diabetes and obesity are showing a rising trend and giving rise to a new epidemic called diabesity. ${ }^{1}$ One in every ten individuals in the United States suffers from diabetes, and about $90-95 \%$ of them have type 2 diabetes (T2DM). ${ }^{2}$ About $79 \%$ of individuals with diabetes live in low and middle income countries (LMIC). ${ }^{3}$ Diabetes is reaching epidemic proportions in all South Asian countries, and more so in India, Pakistan and Bangladesh (Table 1). ${ }^{3}$ If this trend continues, India is projected to have approximately 101 million and 134 million adults with diabetes by 2030 and 2045 , respectively. ${ }^{1,3}$

The rising trend in obesity in LMICs of South Asia (Table 1) is linked to improved socioeconomic status, increase in sedentary lifestyle and adoption of a calorie-rich Westernized diet. ${ }^{4,5}$

\section{Background and Rationale}

This guideline is prepared to address many gaps in the current day practice of nonpharmacological management of diabesity. There are many guidelines on dietary management of diabetes or obesity globally and also from South Asia. However, there are no guidelines or recommendations that address both diabetes and obesity and thus diabesity in the South Asian region. Additionally, the existing diabetes and 
Table I Diabetes and Obesity Burden in South Asia

\begin{tabular}{|c|c|c|c|c|c|c|c|c|}
\hline $\begin{array}{l}\text { Diabetes } \\
\text { Estimates } \\
(20-79 \\
\text { Years) }\end{array}$ & India & Pakistan & Bangladesh & Myanmar & Sri Lanka & Afghanistan & Nepal & Bhutan \\
\hline $\begin{array}{l}\text { People with } \\
\text { diabetes, in } \\
1,000 \text { s }\end{array}$ & $77,005.6$ & $19,369.8$ & $8,372.2$ & $\mathrm{I}, 282.7$ & $1,232.8$ & $\mathrm{I}, 090.8$ & 696.9 & 46.0 \\
\hline $\begin{array}{l}\text { Deaths } \\
\text { attributable } \\
\text { to diabetes }\end{array}$ & $1,010,262.1$ & $158,973.7$ & $109,857.3$ & $31,288.3$ & $15,459.1$ & $18,630.3$ & $11,678.9$ & 326.7 \\
\hline $\begin{array}{l}\text { Total } \\
\text { diabetes- } \\
\text { related } \\
\text { health } \\
\text { expenditure, } \\
\text { USD million }\end{array}$ & $7,057.4$ & $1,612.8$ & 535.0 & 235.2 & 244.4 & 182.7 & 56.0 & 7.6 \\
\hline $\begin{array}{l}\text { Obesity } \\
\text { burden in } \\
\text { South Asia }\end{array}$ & $\begin{array}{l}\text { Burden varies by } \\
\text { state and } \\
\text { socioeconomic } \\
\text { factors. } \\
\text { Percentage of } \\
\text { men/women who } \\
\text { are overweight/ } \\
\text { obese as per } \\
\text { National Family } \\
\text { Health Survey } \\
\text { (NHFS)-3 } \\
\text { (2005-2006): } \\
30.3 \% \text { men and } \\
37.5 \% \text { women in } \\
\text { Punjab (North); } \\
24.3 \% \text { men and } \\
34 \% \text { women in } \\
\text { Kerala } \\
\text { NHFS-4 } \\
\text { (20I5-2016): } \\
>15 \% \text { of adults } \\
\text { were overweight/ } \\
\text { obese in 19 } \\
\text { states; of these, } \\
\text { in } 6 \text { states >25\% } \\
\text { of adults were } \\
\text { overweight/ } \\
\text { obese } 8,83,84\end{array}$ & $\begin{array}{l}\text { BMI >30 } \\
\text { was seen in } \\
30.5 \% \text { of } \\
\text { population; } \\
\text { Obesity in } \\
\text { women } \\
(56.7 \%) \text { and } \\
\text { obesity in } \\
\text { men } \\
(43.3 \%)^{85}\end{array}$ & $\begin{array}{l}\text { Prevalence } \\
\text { of } \\
\text { overweight } \\
\text { and obesity } \\
\text { in urban } \\
\text { women was } \\
34 \%^{86}\end{array}$ & $\begin{array}{l}\text { Overweight: } \\
20.6 \% \text { males } \\
\text { and } 29.96 \% \\
\text { females } \\
\text { Obesity: } \\
4.77 \% \text { in } \\
\text { males and } \\
10.35 \% \text { in } \\
\text { females }{ }^{87}\end{array}$ & $\begin{array}{l}\text { Global BMI vs } \\
\text { Asian cut-offs: } \\
\text { underweight } \\
\text { ( } 7.7 \% \text { vs } 7.7 \%) \text {, } \\
\text { normal weight } \\
\text { ( } 39.6 \% \text { vs } 26.8 \%) \text {, } \\
\text { overweight } \\
\text { ( } 37.0 \% \text { vs } 34.3 \% \text { ) } \\
\text { and obesity } \\
\text { ( } 15.8 \% \text { vs.31.2\%). } \\
\text { The community } \\
\text { prevalence for } \\
\text { abdominal } \\
\text { obesity was } \\
58.1 \% \text { when using } \\
\text { Asian cut-offs. }\end{array}$ & $\begin{array}{l}2016: 36.9 \% \\
\text { of adults: } \\
\text { male: } 32.7 \% \\
\text { and female: } \\
41.2 \%^{89} \\
2020: \\
\text { Overweight: } \\
\text { 19\%, general } \\
\text { obesity: } \\
33.7 \% \text { and } \\
\text { abdominal } \\
\text { obesity: } \\
57.1 \%{ }^{90}\end{array}$ & $\begin{array}{l}\text { Nation-wide } \\
2016 \text { survey } \\
\text { (overweight/ } \\
\text { obesity): } \\
\text { women } \\
32.87 \% \text { and } \\
\text { men } \\
28.77 \%{ }^{91}\end{array}$ & $\begin{array}{l}\text { WHO } 2016 \\
\text { data: } \\
\text { Overweight: } \\
24.8 \% \text {, obese: } \\
5.9 \%{ }^{92} \\
\text { According to } \\
\text { a } 2018 \text { report, } \\
\text { one-third of the } \\
\text { Bhutan } \\
\text { population is } \\
\text { overweight } \\
(33 \%)^{93,94}\end{array}$ \\
\hline
\end{tabular}

Notes: Data from International DiabetesFederation. ${ }^{3}$

obesity guidelines have more data from the West and minimal data from South Asia.

The South Asian phenotype is very different from the rest of the world. Normal weight obesity (the lean-obese) is a common phenotype in South Asia. ${ }^{6,7}$ South Asian adults have higher body fat, lower skeletal mass, more visceral obesity, higher abdominal obesity, more ectopic fat deposition (in liver, muscle etc) and less subcutaneous fat space at the same or 
lower body mass index (BMI) as compared to the Western world. ${ }^{5,6,8,9}$ Many of these characteristics are genetically determined and unique to the South Asian phenotype. ${ }^{10}$

Even though the dishes from different countries of South Asia look different, they usually have similar macronutrient content across the region. Though the diet in South Asia is often on the higher calorie side (sometimes $>3000$ calories/ day), it does not meet the protein requirements of adults. The South Asian diet is rich in carbohydrates, refined sugar, and processed food and low in fiber, fruits and vegetables. Deep frying, reusing oil for cooking and higher use of trans-fats is common in South Asia. ${ }^{11}$ These dietary practices are very different from Western dietary practices.

South Asia is also witnessing increased exposure to the food industry. This along with an increasingly sedentary lifestyle in this region is complicating the diabesity problem further. There is an urgent need to curb this using technology. One way to utilize technology is to use smartphone applications (apps) that track nutrients, food labels, calorific value of food, footsteps, exercise level, etc and offer custom-made solutions. However, these apps have not been properly integrated in the management of diabesity.

Another unique feature in South Asia is paucity of specialists. The majority of individuals with diabetes, obesity and diabesity are managed by their primary care physicians. With few specialists in South Asia, it is difficult to give person-centric care. Hence, there is an urgent need to formulate practice guidelines for the physicians to follow. Smartphone apps can help patients maintain a healthy diet and lifestyle. They can be useful tools to provide patient-centric care to manage day to day nutrient intake and calorie intake and expenditure.

Medical nutrition therapy (MNT), or dietary advice given by a trained health care professional (HCP), plays a significant role in management of diabesity. However, MNT lacks proper understanding and a structured delivery approach in South Asia. Hence, there is a felt need to train more physicians in diabesity MNT care in South Asia.

Thus, South Asia needs its own guidelines for nonpharmacological management of diabesity in adults due to various reasons discussed in this section. The aim of the Consensus on Medical Nutrition Therapy for Diabesity (CoMeND) in Adults: A South Asian Perspective is to recommend therapeutic and preventive MNT in South Asians suffering from diabesity.

\section{Methodology}

A group of general medicine, endocrine and obesity experts from South Asian countries, that is, Bangladesh, Bhutan, India, Nepal and Sri Lanka, met on January 17, 2020 to frame the Consensus on Medical Nutrition Therapy for Diabesity (CoMeND) in Adults: A South Asian Perspective.

Global and South Asian data on diabetes and obesity was reviewed in detail prior to the meeting. The following guidelines were studied in detail: the American Association of Clinical Endocrinologists (AACE) and American College of Endocrinology (ACE) clinical practice guidelines for obesity, the American Diabetes Association (ADA) Standards of Medical Care in Diabetes for "Obesity Management for the Treatment of Type 2 Diabetes" and "Lifestyle Management", 12,13 a position statement from the Academy of Nutrition and Dietetics, ${ }^{14}$ the Research Society for the Study of Diabetes in India (RSSDI) clinical practice recommendations for the management of type 2 diabetes mellitus, ${ }^{15}$ other food-based dietary guidelines, ${ }^{16}$ the European Association for the Study of Obesity (EASO) position paper, ${ }^{17}$ and guidelines and recommendations for South Asia and India. Several review articles and landmark trials on non-pharmacological management of obesity/diabetes/ diabesity were also reviewed for formulating the Consensus. ${ }^{1,5,18-23}$ Patient-centered care and its benefits in diabesity were also explored. ${ }^{24-27}$

The first draft of the recommendations was prepared and circulated amongst the experts prior to the meeting for their detailed review. At the meeting, the experts provided suggestions, comments and opinions on the draft. The draft was then revised based on the discussions during the meeting and recirculated among the experts for their final suggestions. Post this, the draft was finalized and approved by the experts and sent for publication.

\section{Overview of Recommendations}

The recommendations on non-pharmacological management of diabesity in adults are considered under the following headings:

(I) Screening and Diagnosis

(II) Staging

(III) Medical Nutrition Therapy

- Definition

- Indications

- Goals

- Types of Diets 
- Integrated Approach

- Components

- General Recommendations

(IV) Managing diet in a setting of abundance

(V) Monitoring

(VI) Counselling and Motivation

(VII) Way Forward: Personalized Medicine and Person-centered Care

Also, approximate calorific values of some cooked food preparations are provided in Appendix I. ${ }^{28}$

\section{Screening and Diagnosis}

Recommendation for Screening and Diagnosis

For screening and diagnosis of diabesity, the following should be done: ${ }^{5,29}$
1. History: Detailed history is taken to find the root cause of weight gain (Figure 1). This helps individualize patient treatment based on the identified causes. $^{30}$

2. Physical exam: Double chin, dorsocervical pad of fat, ectopic fat as in sub-scapular, axillary and infraaxillary regions are seen in South Asians. Other things that should be looked for are acanthosis nigricans, xanthelasma, arcus, tendon xanthoma, abdominal striae, gynecomastia, thyroid nodules/swellings.

3. Anthropometry: Height, weight, waist circumference, waist:hip ratio, and body mass index (BMI) should be measured. Other optional investigation: percentage body fat. The South Asian ethnicity specific cut-offs should be used for these obesity indicators as proposed below: ${ }^{31}$

- BMI of $\geq 23 \mathrm{~kg} / \mathrm{m}^{2}$ should be considered as overweight and $\geq 25 \mathrm{~kg} / \mathrm{m}^{2}$ as obese (Table 2). This is

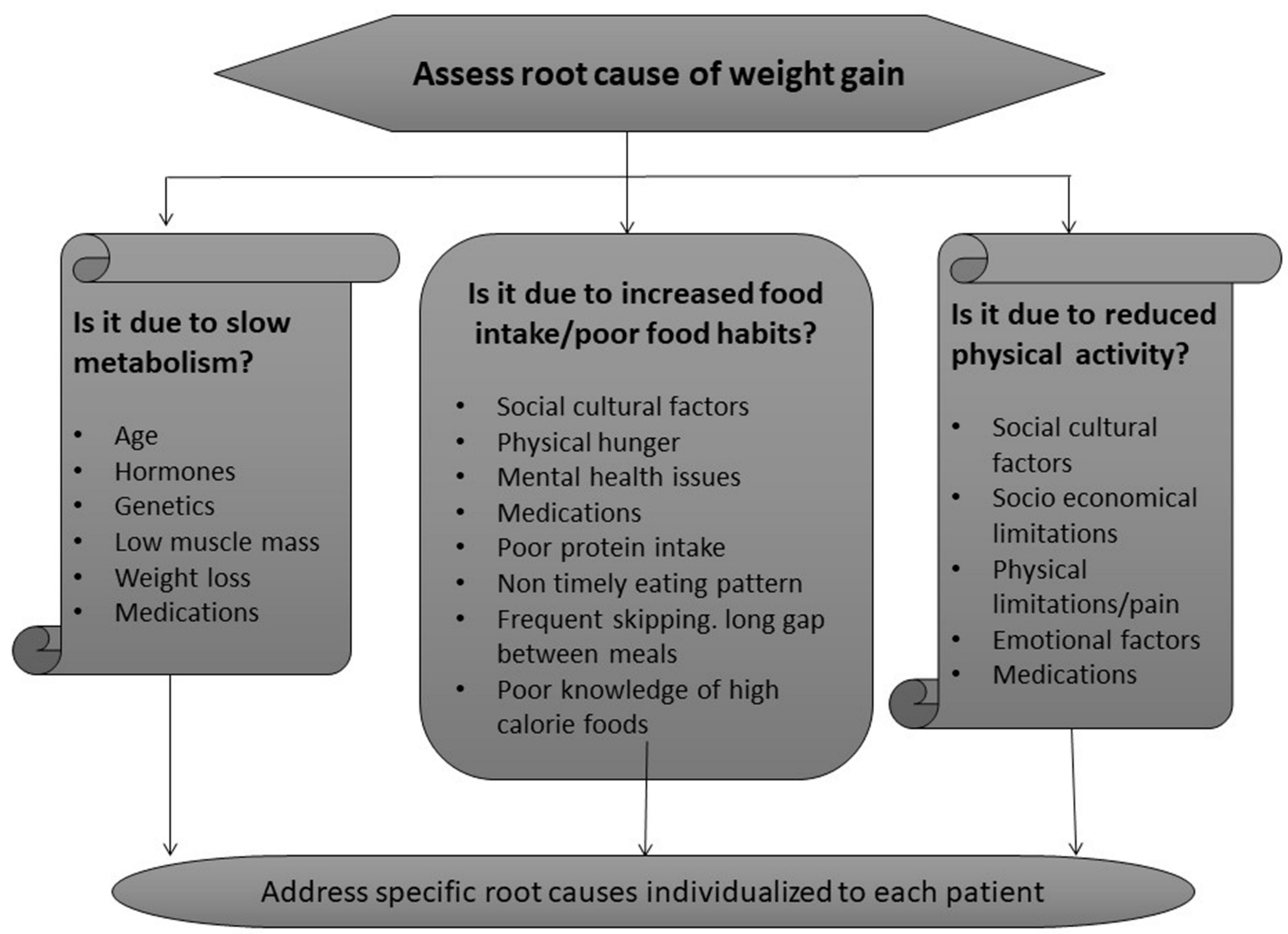

Figure I Root causes of diabesity.

Notes: Data from Kapoor et al. ${ }^{30}$ 
Table 2 Body Mass Index (BMI) Criteria for Obesity in Adults

\begin{tabular}{|c|c|c|}
\hline Category & $A \operatorname{sian}^{37,38}$ & WHO $^{37}$ \\
\hline Underweight & $<18.5$ & $<18.5$ \\
\hline Normal weight & $18.5-22.9$ & $18.5-24.9$ \\
\hline Overweight & $23-24.9$ & $25.0-29.9$ \\
\hline Obesity Grade I & $25-29.9 \mathrm{~kg} / \mathrm{m}^{2}$ & $30.0-34.9$ \\
\hline Obesity Grade II & $30-34.9 \mathrm{~kg} / \mathrm{m}^{2}$ & $35.0-39.9$ \\
\hline Obesity Grade III & $>35 \mathrm{~kg} / \mathrm{m} 2$ & $\geq 40$ \\
\hline
\end{tabular}

in agreement with ADA, WHO and Indian consensus group recommendations for BMI cut-off in Asians. ${ }^{21,32-34}$

- At BMI of $\geq 23 \mathrm{~kg} / \mathrm{m}^{2}$ screening for diabetes should be initiated. ${ }^{21,32}$

- Waist circumference indicates visceral fat and is a useful predictor of cardiometabolic risk and can be combined with BMI. It can be measured at regular intervals to note decrease in visceral fat. ${ }^{35}$

- Other anthropometric measures which can be combined with BMI include: the ratio of waist circumference to hip circumference (waist:hip ratio ([WHR]), and the ratio of waist circumference to height (waist:height ratio). ${ }^{36}$

- Body fat percentage and visceral adipose tissue estimation, though currently used only in the research setting, has significant relevance in the South Asian population. ${ }^{6}$ As per the American Society of Endocrinologists, the cut-off for total body fat percentage is $35 \%$ for women and $25 \%$ for men; however, for Asians, a cut-off of $20.6 \%$ in men and $33.4 \%$ in women has been suggested. ${ }^{7}$

4. Laboratory tests: Glycated hemoglobin ( $\mathrm{HbAlc})$, fasting and postprandial glucose, fasting lipid panel and albumin/creatinine ratio should be done. Based on clinical suspicion, other assessments may include uric acid, hepatic transaminases and serum cortisol.

5. The $4 \mathrm{Ms}$ of assessment: The complete diabesity assessment framework should consider the 4 Ms: Metabolic, Mechanical, Mental and Monetary (Table 3).This helps in holistic management of the patients. ${ }^{30}$

\section{Limitations of Obesity Assessment Measures}

Physicians often use only BMI for measuring obesity. Though BMI is a very popular method of assessing
Table 3 The 4 Ms of Diabesity Assessment

\begin{tabular}{|l|l|l|l|}
\hline Metabolic & Mechanical & Mental & Monetary \\
\hline $\begin{array}{l}\text { Type 2 diabetes } \\
\text { mellitus }\end{array}$ & Sleep apnea & Cognition & Education \\
\hline Dyslipidemia & Osteoarthritis & Depression & Employment \\
\hline Hypertension & Chronic pain & Attention deficit & Income \\
\hline Gout & Reflux disease & Addiction & Disability \\
\hline Fatty liver & Incontinence & Psychosis & Insurance \\
\hline Gall stones & Thrombosis & Eating disorder & Benefits \\
\hline $\begin{array}{l}\text { Polycystic } \\
\text { ovarian syndrome }\end{array}$ & Intertrigo & Trauma & $\begin{array}{l}\text { Bariatric } \\
\text { supplies }\end{array}$ \\
\hline Malignancy & $\begin{array}{l}\text { Plantar } \\
\text { fasciitis }\end{array}$ & Insomnia & $\begin{array}{l}\text { Weight loss } \\
\text { programs }\end{array}$ \\
\hline
\end{tabular}

Notes:Data from Kapoor et al. ${ }^{30}$

(screening and diagnosis) obesity, it has some limitations which the clinicians should be aware of: ${ }^{6,7}$

1. Asian-specific BMI and not the WHO Global BMI parameters should be used to assess obesity in South Asians. ${ }^{32,37,38}$

2. BMI should not be used as the only method to assess obesity. BMI should be combined with, at minimum, a waist circumference to capture adiposity correctly (Table 4).

- BMI does not distinguish between muscle weight and fat weight. Though it has high specificity for obesity, it has very low sensitivity for adiposity. Therefore, approximately $50 \%$ of individuals with excess fat fail to be classified as overweight/obese. ${ }^{39}$

- BMI is unable to catch body fat distribution, which is a marker of metabolic disturbance, cardiovascular risk and linked to $\mathrm{T}_{2} \mathrm{DM} .^{40-42}$

Table 4 Parameters Used to Define Obesity in South Asians

\begin{tabular}{|l|l|}
\hline Parameter Studied & Criteria for Overweight/Obesity \\
\hline Body mass index & $>23 \mathrm{~kg} / \mathrm{m}^{2}$ \\
Waist circumference & $>90 \mathrm{~cm}$ in men and $>80 \mathrm{~cm}$ in women \\
Waist:hip ratio & 0.9 in men and 0.8 in women \\
Body fat percentage* & $>25 \%$ in men and $>30 \%$ in women \\
\hline
\end{tabular}

Notes: *As measured by dual energy $\mathrm{x}$-ray absorptiometry (DEXA) scan. Data from Thomas et al. ${ }^{38}$ 
Hence, for anthropometry, as discussed above, BMI should be combined with the waist:height ratio (WHR).

Other investigations which can be combined with BMI, if required, are (not usually done):

1. Dual-energy x-ray absorptiometry (DEXA) or air displacement plethysmography, which accurately assess lean body mass and body fat. DEXA is the gold standard to assess body composition. However, neither of these tests can be used routinely as they are very costly.

2. Measuring body water using bioelectric impedance is a relatively inexpensive method. It compares body fat mass with fat-free mass. However, large inter-individual variations limit its use. ${ }^{43}$

\section{Staging of Obesity}

The diabesity therapy is guided by the level of obesity. Hence, physicians should be able to identify the stage of obesity and its biochemical parameters. This can be done using well-designed models. The SECURED (Severity of obesity, Expected prognosis, Comorbid conditions, Urgency of control, Risk of complications, Environmental factors, Dysfunction and disability) model (Table 5) lists the parameters that should be considered while developing patient/person-centered care. $^{44}$ The Edmonton Obesity Staging System (EOSS) (Table 6) or

Table 5 SECURED Model

\begin{tabular}{|c|l|l|}
\hline S & $\begin{array}{l}\text { Severity of } \\
\text { obesity }\end{array}$ & Body mass index, waist circumference \\
\hline E & $\begin{array}{l}\text { Expected } \\
\text { prognosis }\end{array}$ & Expected life span \\
\hline C & $\begin{array}{l}\text { Comorbid } \\
\text { conditions }\end{array}$ & $\begin{array}{l}\text { Metabolic, mechanical and mood } \\
\text { disturbances }\end{array}$ \\
\hline U & $\begin{array}{l}\text { Urgency of } \\
\text { control }\end{array}$ & $\begin{array}{l}\text { Biomedical or psychosocial issues that } \\
\text { require early weight control }\end{array}$ \\
\hline R & $\begin{array}{l}\text { Risk of } \\
\text { complications }\end{array}$ & $\begin{array}{l}\text { Risk of malnutrition, gall stones, other } \\
\text { complications due to rapid weight loss }\end{array}$ \\
\hline E & $\begin{array}{l}\text { Environmental } \\
\text { factors }\end{array}$ & $\begin{array}{l}\text { Socioeconomic factors influencing life with } \\
\text { obesity }\end{array}$ \\
\hline D & $\begin{array}{l}\text { Dysfunction and } \\
\text { disability }\end{array}$ & $\begin{array}{l}\text { Biopsychosocial dysfunction and disability } \\
\text { due to obesity }\end{array}$ \\
\hline
\end{tabular}

Notes: Data from Kalra et al. ${ }^{44}$ the Cardiometabolic Disease Staging (CMDS) system (Table 7) can help identify the stage of obesity and plan the intervention accordingly.

\section{Recommendations}

Physicians can use any of the models in Tables 5, 6 and 7 to assess the stage of obesity and plan the diabesity intervention accordingly.

\section{Overview of Management of Diabesity}

Diabesity can be managed by non-pharmacological, pharmacological and surgical interventions. Treating obesity is the primary focus. T2DM remission should aim to be a natural progression of weight control. Pharmacotherapy with anti-obesity medications and glucose-lowering agents should be started where required. Surgical interventions should be considered in patients who cannot be managed through anti-obesity medications and glucose-lowering agents. However, irrespective of pharmacological and surgical approach used, the focus should be on lifestyle management which primarily includes focus on diet and physical exercise. BMI may be used to guide the type of intervention in diabesity (Table 8 ). However, all treatment decisions should be made based on the patient's general condition, contraindications for pharmacotherapy/surgery and severity of comorbid conditions.

\section{Dietary Concerns in Diabesity}

Lifestyle habits need to be changed to prevent and therapeutically cure diabesity, which includes reduced daily calorie intake along with aerobic and strengthbuilding exercises. Many food habits cause obesity/ abdominal obesity in South Asians such as (but not limited to): $:^{5,11}$

1. Excess consumption of refined carbohydrates, sweets and sweetened beverages

2. Using saturated fats for cooking

3. Frequent consumption of fried snacks or snacks made with highly saturated fat

4. Low fruit and vegetable intake resulting in low fiber intake

5. Increased intake of calorie-dense food

People with obesity often fail to comply with a diet because they prefer highly processed simple sugar 
Table 6 Edmonton Obesity Staging System (EOSS)

\begin{tabular}{|c|c|c|c|c|}
\hline $\begin{array}{l}\text { EOSS } \\
\text { Stage }\end{array}$ & Level of Obesity and Complications & Biochemical Parameters & $\begin{array}{l}\text { Level of } \\
\text { Prevention }\end{array}$ & Intervention \\
\hline 0 & $\begin{array}{l}\text { No apparent obesity-related risk factors, } \\
\text { symptoms, psychopathology, limitations, } \\
\text { and/or well-being impairments }\end{array}$ & No EOSS factors reported & $\begin{array}{l}\text { Primordial/ } \\
\text { No } \\
\text { intervention }\end{array}$ & $\begin{array}{l}\text { Healthy lifestyle to be } \\
\text { encouraged }\end{array}$ \\
\hline 1 & $\begin{array}{l}\text { Subclinical obesity risk factors, physical } \\
\text { symptoms, psychopathology, functional } \\
\text { limitations, and/or well-being impairment is } \\
\text { mild }\end{array}$ & $\begin{array}{l}\text { Any of the following: } \\
\text { i) Fasting glucose } \geq 100 \mathrm{mg} / \mathrm{dL} \\
\text { (ii) Cholesterol } \geq 200 \mathrm{mg} / \mathrm{dL} \\
\text { (iii) Triglycerides } \geq 150 \mathrm{mg} / \mathrm{dL} \\
\text { (iv) } \mathrm{HDL} \leq 60 \mathrm{mg} / \mathrm{dL} \\
\text { (v) Fasting } \mathrm{LDL} \geq 100 \mathrm{mg} / \mathrm{dL} \\
\text { (vi) } \mathrm{SBP} \geq 130 \mathrm{mmHg} \\
\text { (vii) } \mathrm{DBP} \geq 85 \mathrm{mmHg}\end{array}$ & Primordial & Lifestyle modification \\
\hline 2 & $\begin{array}{l}\text { Established obesity, moderate limitations in } \\
\text { activities of daily living, and/or well-being }\end{array}$ & $\begin{array}{l}\text { Any of the following: } \\
\text { (i) Fasting glucose } \geq 124 \mathrm{mg} / \mathrm{dL} \\
\text { (ii) Diagnosed with T2DM or on T2DM } \\
\text { medication } \\
\text { (iii) Total cholesterol } \geq 240 \mathrm{mg} / \mathrm{dL} \\
\text { (iv) Triglycerides } \geq 195 \mathrm{mg} / \mathrm{dL} \\
\text { (v) } \mathrm{HDL}<40 \mathrm{mg} / \mathrm{dL} \text { (men) and }<50 \mathrm{mg} / \\
\mathrm{dL} \text { in women } \\
\text { (vi) LDL } \geq 160 \mathrm{mg} / \mathrm{dL} \\
\text { (vii) Diagnosed hypercholesterolaemia } \\
\text { or hyperlipidaemia or hyperlipidaemia or } \\
\text { on medication for it } \\
\text { (viii) SBP } \geq 140 \mathrm{mmHg} \\
\text { (ix) DBP } \geq 90 \text { mmHg } \\
\text { (x) Diagnosed hypertension or } \\
\text { hypertension medication } \\
\text { (xi) Any of the following comorbidities: } \\
\text { Sleep apnea, gout, arthritis, anxiety, } \\
\text { atherosclerosis, fatty liver, congestive } \\
\text { heart failure medication, depression, on } \\
\text { blood thinners }\end{array}$ & Primary & $\begin{array}{l}\text { Behavioral therapy with } \\
\text { supportive medication } \\
\text { therapy for biochemical } \\
\text { abnormalities and } \\
\text { comorbidities }\end{array}$ \\
\hline 3 & $\begin{array}{l}\text { Established end-organ damage, significant } \\
\text { psychopathology, significant functional } \\
\text { limitations, and/or well-being impairment }\end{array}$ & $\begin{array}{l}\text { Any of the following: } \\
\text { (i) Angina } \\
\text { (ii) Heart attack } \\
\text { (iii) Heart failure } \\
\text { (iv) Thrombosis } \\
\text { (v) Coronary artery disease } \\
\text { (vi) Coronary obstructive pulmonary } \\
\text { disease } \\
\text { (vii) Dyspnea } \\
\text { (viii) Exercise dyspnea } \\
\text { (ix) Coronary artery bypass surgery } \\
\text { (x) Stroke }\end{array}$ & Secondary & Medical therapy/Surgery \\
\hline 4 & $\begin{array}{l}\text { Severe (potentially end-stage) disabilities } \\
\text { from obesity-related chronic diseases, } \\
\text { disabling psychopathology, functional } \\
\text { limitations, and/or well-being impairment }\end{array}$ & No data available to evaluate this stage & Tertiary & Bariatric surgery \\
\hline
\end{tabular}

Notes: Data from these studies. ${ }^{44,95,96}$

Abbreviations: DBP, diastolic blood pressure; HDL, high-density lipoprotein; LDL, low-density lipoprotein; SBP, systolic blood pressure; T2DM, type 2 diabetes mellitus. 
Table 7 Cardiometabolic Disease Staging (CMDS)

\begin{tabular}{|c|c|c|c|c|}
\hline Stage & Descriptor & Criteria & $\begin{array}{l}\text { Level of } \\
\text { Prevention }\end{array}$ & Intervention \\
\hline 0 & $\begin{array}{l}\text { Metabolically } \\
\text { healthy }\end{array}$ & No risk factors & $\begin{array}{l}\text { Primordial/ } \\
\text { No } \\
\text { intervention }\end{array}$ & Healthy lifestyle to be encouraged \\
\hline I & $\begin{array}{l}\text { One or two } \\
\text { risk factors }\end{array}$ & $\begin{array}{l}\text { Have one or two of the following risk factors: } \\
\text { (a) High waist circumference }(\geq 80 \mathrm{~cm} \text { in South Asian } \\
\text { women and } \geq 90 \mathrm{~cm} \text { in South Asian men) } \\
\text { (b) Elevated blood pressure (systolic } \geq 130 \mathrm{mmHg} \text { and/or } \\
\text { diastolic } \geq 85 \mathrm{mmHg} \text { ) or on antihypertensive medication } \\
\text { (c) Reduced serum } \mathrm{HDL} \text { cholesterol }(<40 \mathrm{mg} / \mathrm{dL} \text { in men; } \\
<50 \mathrm{mg} / \mathrm{dL} \text { in women) } \\
\text { (d) Elevated fasting serum triglycerides }(\geq 150 \mathrm{mg} / \mathrm{dL} \text { ) }\end{array}$ & Primordial & Lifestyle modification \\
\hline 2 & $\begin{array}{l}\text { Metabolic } \\
\text { syndrome or } \\
\text { prediabetes }\end{array}$ & $\begin{array}{l}\text { Have only one of the following three conditions in isolation: } \\
\text { (a) Metabolic syndrome based on three or more of four risk } \\
\text { factors: high waist circumference, elevated blood pres- } \\
\text { sure, reduced HDL-C, and elevated triglycerides } \\
\text { (b) Impaired fasting glucose (fasting glucose } \geq 100 \mathrm{mg} / \mathrm{dL} \text { ) } \\
\text { (c) Impaired glucose tolerance (2-h glucose } \geq 140 \mathrm{mg} / \mathrm{dL} \text { ) }\end{array}$ & Primary & $\begin{array}{l}\text { Behavioral therapy with supportive } \\
\text { medication therapy for biochemical } \\
\text { abnormalities and comorbidities }\end{array}$ \\
\hline 3 & $\begin{array}{l}\text { Metabolic } \\
\text { syndrome } \\
\text { and } \\
\text { prediabetes }\end{array}$ & $\begin{array}{l}\text { Have any two of the following three conditions: } \\
\text { (a) Metabolic syndrome } \\
\text { (b) IFG } \\
\text { (c) IGT }\end{array}$ & Secondary & Medical therapy/Surgery \\
\hline 4 & $\begin{array}{l}\text { T2DM and/or } \\
\text { CVD }\end{array}$ & $\begin{array}{l}\text { Have T2DM and/or CVD: } \\
\text { (a) T2DM (fasting glucose } \geq 126 \mathrm{mg} / \mathrm{dL} \text { or } 2 \text {-h glucose } \\
\geq 200 \mathrm{mg} / \mathrm{dL} \text { or on antidiabetic therapy) } \\
\text { (b) Active CVD (angina pectoris, or status after a CVD } \\
\text { event such as acute coronary artery syndrome, stent } \\
\text { placement, coronary artery bypass, thrombotic stroke, } \\
\text { nontraumatic amputation due to peripheral vascular } \\
\text { disease) }\end{array}$ & Tertiary & Bariatric surgery if medically fit \\
\hline
\end{tabular}

Notes:Data from these studies. ${ }^{44,97}$

Abbreviations: CVD, cardiovascular disease; HDL-C, high-density lipoprotein cholesterol; IFG, impaired fasting glucose; IGT, impaired glucose tolerance; T2DM, type 2 diabetes mellitus.

Table 8 BMI Cut-Offs for Management of Obesity in South Asians

\begin{tabular}{|l|l|l|l|l|l|l|}
\hline BMI Asian in kg/m² & 23-24.9 Overweight & 25-26.9 Grade I & 27-29.9 Grade I & 30-34.9 Grade II & $\geq 37.5$ Grade III \\
\hline Therapy & $\Pi$ & $\Pi$ & $\Pi$ & $\Pi$ & $\Pi$ \\
\hline Diet, exercise, behavioral therapy & $\Pi$ & $\Pi$ if comorbidities & $\Pi$ & & $\Pi$ & $\Pi$ \\
\hline Pharmacotherapy & & & $\Pi$ if comorbidities & $\Pi$ \\
\hline Bariatric surgery & & &
\end{tabular}

Notes:Data from these studies. ${ }^{5,21}$ 
containing foods instead of complex/raw carbohydrates. High glycemic index food stimulates serotonin secretion, which, apart from providing a feeling of well being, also increases a craving for carbohydrates. ${ }^{45}$

\section{Medical Nutrition Therapy Definition}

MNT is the provision of nutritional assessment, advice and follow-up, for prevention and/or management of disease, by a qualified or trained health care provider (HCP). MNT includes dietary, nutritional and culinary advice. It includes both home-made food and medical-grade formulations. As well as diet-related content, MNT also encompasses style of communication and counselling. In the context of diabesity, MNT aims to manage both dysglycemia and adiposity through nutritional intervention.

\section{Indications of Medical Nutrition Therapy}

MNT should be integrated into care of all individuals who require glucose control and weight management: either to decrease or increase weight or maintain weight.

MNT is ideal for patients who have: ${ }^{46}$

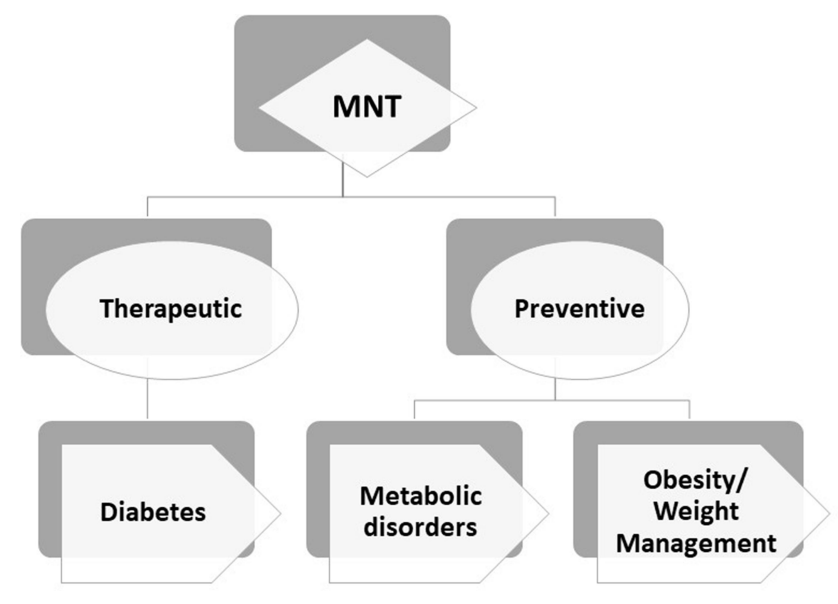

Figure 2 Classification of MNT: therapeutic/preventive. Notes: Data from these studies. ${ }^{46-48}$

- Dietary restrictions due to disease (such as kidney disease)

- A busy lifestyle and lack of resources for healthy cooking

- Chewing, swallowing or dextromotor limitations

- An unwillingness to adhere to a strict diet regime

- Cardio-metabolic comorbidities

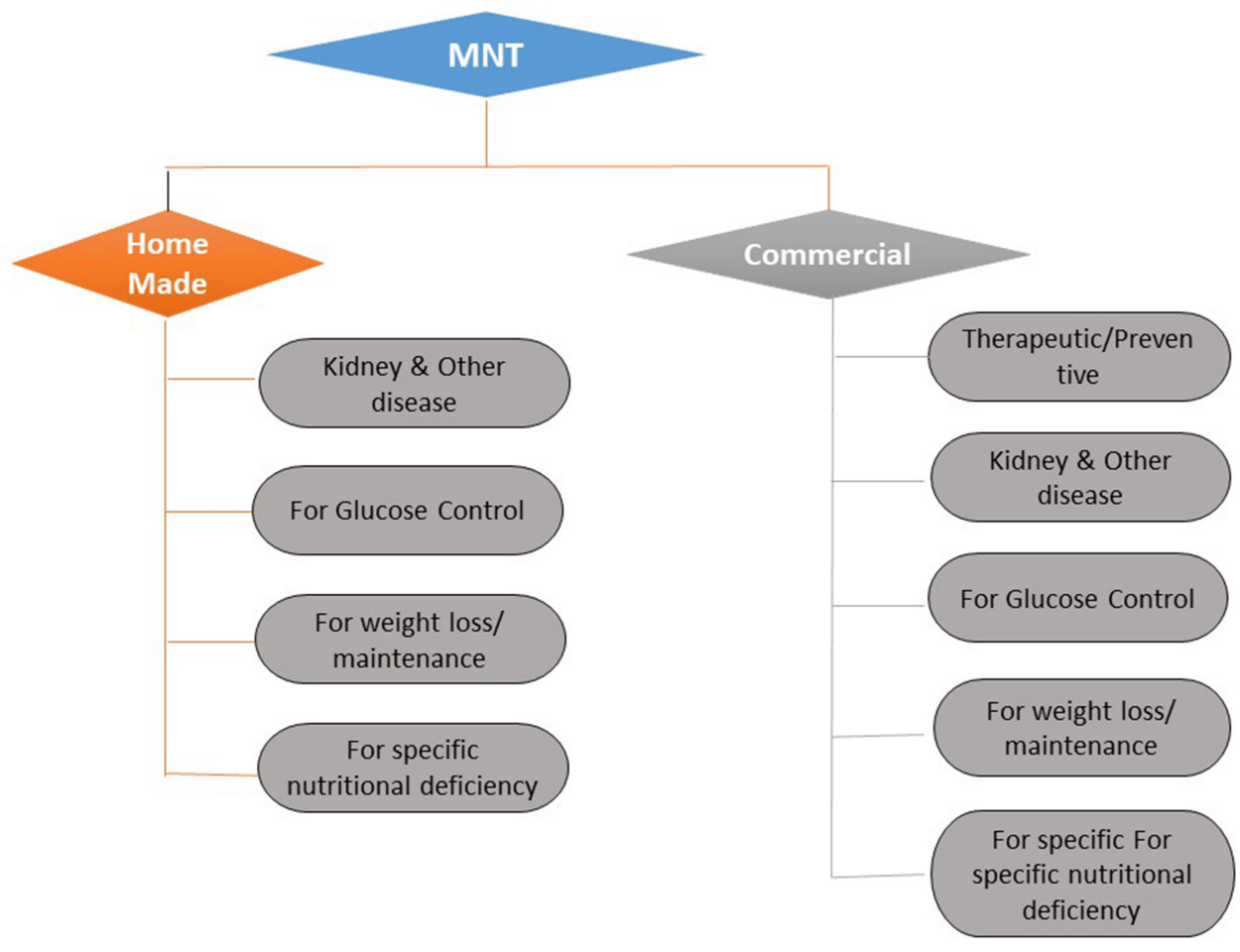

Figure 3 Classification of MNT: home-made/commercial.

Notes: Data from these studies. ${ }^{46-48}$ 


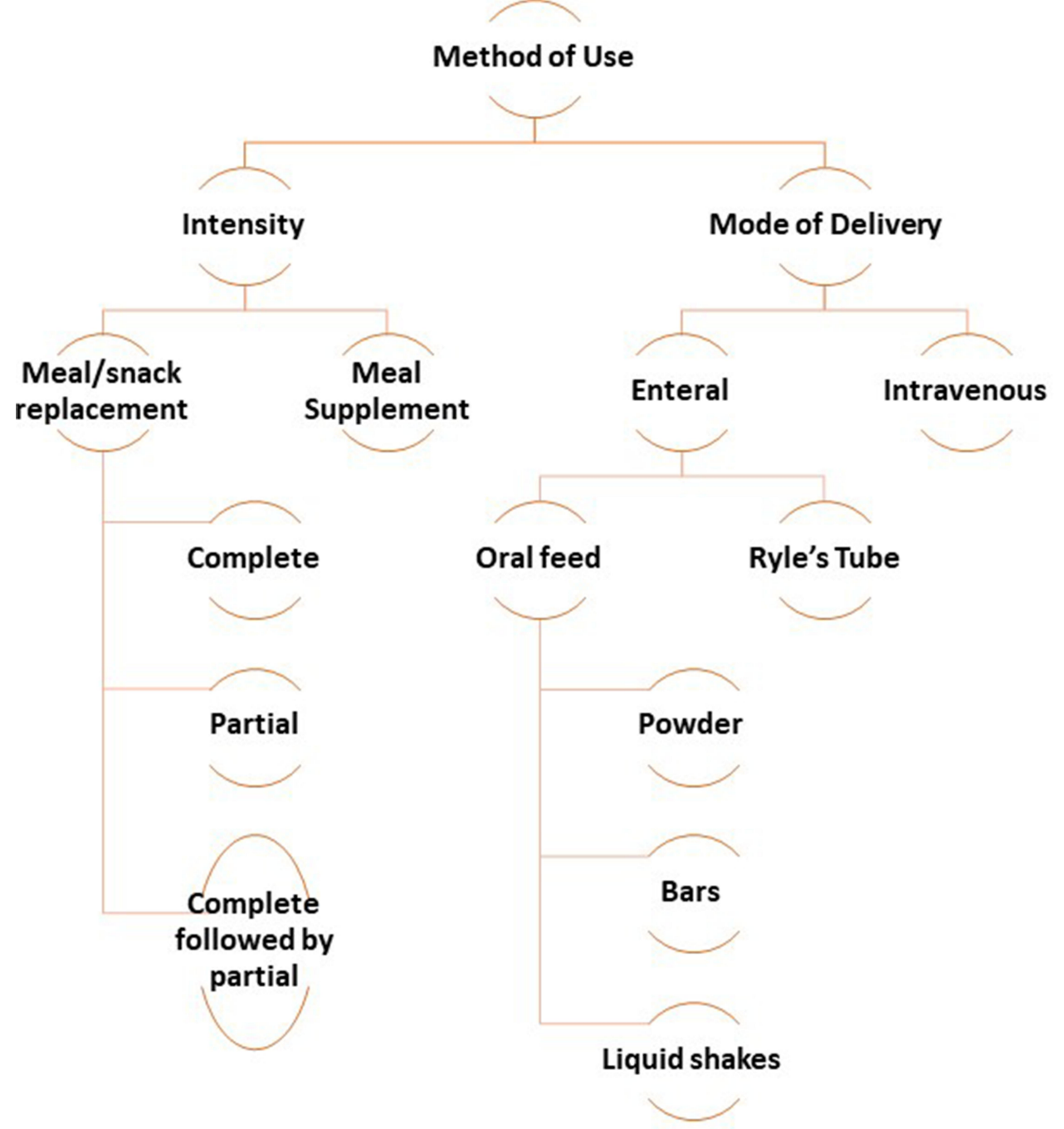

Figure 4 Classification of MNT: method of use.

Notes: Data from these studies. ${ }^{46-48}$

\section{Classification of Medical Nutrition Therapy}

MNT can be classified based on whether it is being given in a therapeutic or preventive setting (Figure 2), whether it is home-made or a commercial preparation (Figure 3) or depending on method of use (Figure 4). ${ }^{46-48}$

\section{Goals of Medical Nutrition Therapy}

1. Attain and maintain individualized glycemic, blood pressure, lipid and weight goals.

2. Delay or prevent complications.

- $\mathrm{A} 1 \mathrm{C}: 7 \%$

- Blood pressure: $120 / 80$ to $140 / 80 \mathrm{mmHg}$

- LDL cholesterol: $100 \mathrm{mg} / \mathrm{dL}$

- HDL cholesterol: $40 \mathrm{mg} / \mathrm{dL}$ for men; HDL cholesterol $0.50 \mathrm{mg} / \mathrm{dL}$ for women

- Triglycerides: $150 \mathrm{mg} / \mathrm{dL}$

\section{Goals for Obesity}

According to the Position Statement of the Academy of Nutrition and Dietetics (2016), the weight management should be aimed at: ${ }^{50}$

- Preventing further weight gain

- Reducing body weight

\section{Goals for Diabetes}

The ADA recommends the following goals for diabetes: ${ }^{49}$ 
o Short-term goal: 5 to $10 \%$ loss, or 0.5 to $1 \mathrm{~kg}$ per week

○ Interim goal: Maintenance

○ Long-term goal: Additional weight loss, if desired

- Maintaining the achieved lower body weight over the long term

Weight management in certain populations (such as eating disorders, pregnancy, receiving chemotherapy) will need to be individualized to their specific needs.$^{50}$ For example, the goals of MNT in gestational diabetes are to support maternal, placental and fetal metabolic requirements. It is the first step to introduction of a healthy eating pattern in mothers and therefore their children for the rest of their lives. $^{51}$

\section{Challenges of Providing Medical Nutrition Therapy in South Asia}

In the advanced countries, MNT forms an integral part of diabetes and obesity care, is person-centric, and necessary for proper management of the disease as the "only therapy" or as a therapy in addition to pharmacotherapy/surgery. ${ }^{52}$ However, in South Asian countries like India, MNT is not covered by insurance. Physicians are not sensitized enough to place as much emphasis on MNT as on pharmacotherapy/ surgery. Hence, mainstreaming MNT is a challenge in these regions. ${ }^{52}$

Additionally, most hospital and clinical settings in this region provide pre-printed standardized MNT charts/dietary options/dos and don'ts/list of healthy snacks/macronutrient alternatives etc. There is very little scope for a registered dietician (RD) to make individual specific changes based on medical requirement, psychosocial preference, culinary practices and taste. ${ }^{52}$

It is therefore important to integrate MNT given by an $\mathrm{RD}$ into the primary care of a patient with diabesity with an aim to restrict calories, improve metabolic parameters and achieve weight loss. ${ }^{53,54}$

\section{Different Types of Diets}

Evidence shows that MNT is effective in reducing weight and resolving T2DM. ${ }^{18,19,55,56}$ However, responses to a different diet varied in participants. Each diet type had its own benefits. In the Look AHEAD trial, the arm with intensive lifestyle intervention incorporated partial liquid meal replacement to achieve dietary goals. Participants in the intensive lifestyle intervention group lost significantly more weight than DSE participants at year 1 and year 4 (net difference, $-7.9 \%$ and $-3.9 \%$, respectively). ${ }^{19}$

Depending on the calorie intake, a hypocaloric diet $\leq 1200 \mathrm{kcal} /$ day) can be a low-calorie diet (LCD; 800 to $1200 \mathrm{kcal} / \mathrm{day}$ ) and a very-low-calorie diet (VLCD; 200-800 kcal/day). If carbohydrate in VLCD is restricted to about $50 \mathrm{~g} /$ day, it is known as a very-low-calorie ketogenic diet (VLCKD) ${ }^{57}$ The RSSDI recommends the lowcarbohydrate ketogenic diet over the low-calorie diet. ${ }^{15}$

In the DIRECT trial, participants randomized to low fat, Mediterranean and low carbohydrate diets lost approximately $2.9 \mathrm{~kg}, 4.4 \mathrm{~kg}$ and $4.7 \mathrm{~kg}$, respectively. The low carbohydrate arm showed a greater decrease in triglyceride levels than the low fat arm. Only the Mediterranean diet could decrease fasting glucose in patients with diabetes. All groups showed a decrease in insulin levels. Though HDL levels increased in all groups, the low carbohydrate group showed a higher increase in HDL than the low fat group. ${ }^{56}$

In the POUNDS Lost study, weight loss was similar in the low fat/average protein (highest carbohydrate), low fat/ high protein, high fat/average protein and high fat/high protein (lowest carbohydrate) arms (2.9 kg vs $3.8 \mathrm{~kg}$, vs $3.9 \mathrm{~kg}$ vs $3.5 \mathrm{~kg}) .{ }^{58} \mathrm{HDL}$ cholesterol increase was greater with the lowest versus highest carbohydrate diet. All diets except the highest carbohydrate increased fasting insulin.

MNT is also effective as a first-line therapy in gestational diabetes mellitus (GDM) ${ }^{51}$ A sub-analysis of the $\mathrm{St}$ Carlos GDM Prevention Study showed that Mediterranean diet (MedDiet)-based MNT in GDM resulted in nearnormoglycaemia and pregnancy outcomes were similar to women who did not have diabetes during pregnancy. ${ }^{55}$

Diet patterns, composition, quantity, advantages and disadvantages of various types of diets are included in Table 9. This is just for guidance, and many dietary patterns may overlap in a patient.

\section{Step-Wise Integrated Approach for Medical Nutrition Therapy}

In their white paper on diabetes, Daly et al (2009) note that MNT provides

more intensive nutrition counselling and a therapy regimen that relies heavily on follow-up and feedback to assist patients with changing their behavior(s).... ${ }^{59}$

MNT cannot be generalized. It has to be individualized to patient need and involve proper diagnosis, nutritional assessment and counselling. MNT needs to be provided 
Table 9 Various Types of Diets in Diabesity and Their Advantages and Disadvantages

\begin{tabular}{|c|c|c|c|c|}
\hline Type of Diet & Definition & Reported Benefits & Reported Limitations & Comments \\
\hline $\begin{array}{l}\text { Low carbohydrate } \\
\text { diet }\end{array}$ & $\begin{array}{l}<26 \% \text { carbohydrates or } \\
<130 \mathrm{gm} / \text { day }^{98}\end{array}$ & $\begin{array}{l}\text { Beneficial effect on HbAlc } \\
\text { level compared to normal } \\
\text { carbohydrate diet; May be } \\
\text { beneficial to cardiovascular } \\
\text { risk factors, according to } \\
\text { summaries of data of } \\
\text { triglycerides and HDL-C; } \\
\text { Some studies indicated short- } \\
\text { term effects on weight } \\
\text { loss } 99,100\end{array}$ & 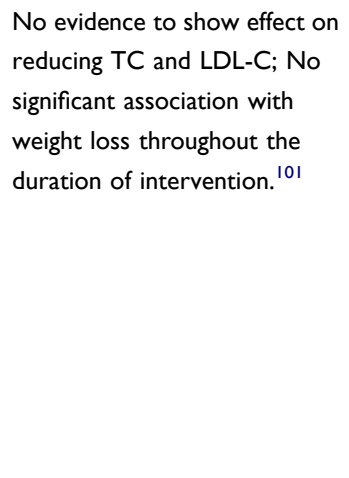 & $\begin{array}{l}\text { Watery and traditional Indian } \\
\text { non-starchy vegetables low in } \\
\text { carbohydrate (such as salad } \\
\text { greens, cauliflower, cucumber, } \\
\text { bottle gourd, cabbage, etc); fat } \\
\text { from animal foods, oils, butter, } \\
\text { and avocado; and protein in } \\
\text { the form of meat, poultry, fish, } \\
\text { shellfish, eggs, cheese, nuts, } \\
\text { and seeds. Avoids starchy and } \\
\text { sugary foods such as rice, } \\
\text { potatoes, bread, and sweets. }{ }^{49}\end{array}$ \\
\hline $\begin{array}{l}\text { Very-low } \\
\text { carbohydrate diet }\end{array}$ & $\begin{array}{l}<10 \% \text { carbohydrates or } \\
<20-50 \mathrm{gm} / \text { day }^{98}\end{array}$ & $\begin{array}{l}\text { Decreased body weight, } \\
\text { triglycerides and DBP and } \\
\text { increased HDL-C. Achieved } \\
\text { a greater weight loss than } \\
\text { those assigned to a low fat } \\
\text { diet }^{102}\end{array}$ & $\begin{array}{l}\text { Increased LDL. }{ }^{102} \\
\text { Possible occurrence of diabetic } \\
\text { ketoacidosis with SGLT2 } \\
\text { inhibitors. }{ }^{103}\end{array}$ & $\begin{array}{l}\text { Similar to low-carbohydrate } \\
\text { pattern but further limits } \\
\text { carbohydrate-containing foods, } \\
\text { and meals typically derive } \\
\text { more than half of calories from } \\
\text { fat. Often has a goal of } 20-50 \\
g \text { of non-fiber carbohydrate } \\
\text { per day to induce nutritional } \\
\text { ketosis. }\end{array}$ \\
\hline Ketogenic diet & $\begin{array}{l}\text { No carbohydrates; Avoid } \\
\text { excess protein; High fat } \\
\text { (>70\% of calories) }^{15,104}\end{array}$ & $\begin{array}{l}\text { Decreased } \mathrm{HbAlc} \text { and insulin } \\
\text { resistance; Improved lipid } \\
\text { profile }^{105}\end{array}$ & $\begin{array}{l}\text { Likely reduction in endurance } \\
\text { performance; Long-term } \\
\text { impact on weight loss and } \\
\text { physical activity remains } \\
\text { unknown }{ }^{105}\end{array}$ & $\begin{array}{l}\text { Lipid profile should be } \\
\text { monitored while patient is on } \\
\text { this diet and diet adjustments } \\
\text { should be made based on the } \\
\text { lipid profile. }{ }^{15}\end{array}$ \\
\hline $\begin{array}{l}\text { Paleo diet: the } 80 / \\
20 \text {, the } \\
\text { autoimmune, the } \\
\text { lacto, the } \\
\text { Paleolithic vegan } \\
\text { and the Paleolithic } \\
\text { ketogenic }\end{array}$ & $\begin{array}{l}30 \% \text { carbohydrate; lean } \\
\text { protein of } 30-35 \% \text { daily } \\
\text { caloric intake; } 40 \% \text { fat; fiber } \\
\text { (up to } 45-100 \mathrm{~g} \text { daily) from } \\
\text { non-cereal, plant-based } \\
\text { sources }^{106}\end{array}$ & $\begin{array}{l}\text { Rapid weight loss; Liver fat } \\
\text { reduction; Reduces } \\
\text { inflammation; Improves body } \\
\text { microbes; Improved lipid } \\
\text { profiles and glucose } \\
\text { sensitivities; Prevents T2DM } \\
\text { and metabolic syndrome; } \\
\text { Improves nutrition density, } \\
\text { enhances satiety }{ }^{106,107}\end{array}$ & $\begin{array}{l}\text { Expensive; Weight loss at } 24 \\
\text { months is similar to that } \\
\text { achieved by generalized caloric } \\
\text { restriction; Side effects; Low } \\
\text { calcium intake }{ }^{106-108}\end{array}$ & $\begin{array}{l}\text { Diet includes natural } \\
\text { environmental foods (lean } \\
\text { meat, fish, fruits, vegetables, } \\
\text { roots, } \\
\text { eggs, and nuts) and eliminates } \\
\text { grains, legumes and most } \\
\text { processed foods so that it } \\
\text { resembles the diet followed by } \\
\text { human hunter-gatherer } \\
\text { ancestors. }\end{array}$ \\
\hline $\begin{array}{l}\text { Intermittent fasting } \\
\text { (IF) }\end{array}$ & No food consumed, fasting & $\begin{array}{l}\text { Reduction in weight, } \\
\text { triglycerides, insulin, } \\
\text { adiponectin, SBP, and TC; } \\
\text { Lowers risk of CAD; Maintain } \\
\text { lean body mass; May be } \\
\text { sustainable for long periods of } \\
\text { time }\end{array}$ & $\begin{array}{l}\text { Weight regain if there is non- } \\
\text { adherence/non-compliance; } \\
\text { Binge eating on non-fasting } \\
\text { days; Weight loss at } 24 \text { months } \\
\text { is similar to that achieved by } \\
\text { generalized caloric } \\
\text { restriction } \\
107,108\end{array}$ & $\begin{array}{l}\text { Time-restricted IF: Eating only } \\
\text { during certain hours of the day, } \\
\text { for example } 16 \text { hours fasting } \\
\text { and eating during remaining } 8 \\
\text { hours } \\
\text { Complete IF: Not eating at all } \\
\text { on fasting days, for example } \\
\text { alternate day fasting, twice } \\
\text { a week fasting } \\
\text { Modified IF: Eating } 20-25 \% \text { of } \\
\text { basal calorie needs on fasting } \\
\text { days. }{ }^{108}\end{array}$ \\
\hline
\end{tabular}

(Continued) 
Table 9 (Continued).

\begin{tabular}{|c|c|c|c|c|}
\hline Type of Diet & Definition & Reported Benefits & Reported Limitations & Comments \\
\hline Atkins diet & $\begin{array}{l}\text { No calorie restriction; Low } \\
\text { carbohydrate; Unrestricted } \\
\text { protein and fat }{ }^{108}\end{array}$ & $\begin{array}{l}\text { Reduction in weight, TG, LDL, } \\
\mathrm{TC}, \mathrm{TC} / \mathrm{LDL} \text { ratio, LDL/HDL } \\
\text { ratio, leptin, and insulin DBP, } \\
\text { SBP, CRP, } \\
\text { Improved HDL, insulin } \\
\text { sensitivity, and adiponectin }\end{array}$ & $\begin{array}{l}\text { Weight regain; Poor } \\
\text { compliance; Fluctuating LDL }{ }^{108}\end{array}$ & $\begin{array}{l}\text { Induction phase }(2 \text { weeks })=< \\
20 \mathrm{~g} / \text { day carbohydrate } \\
\text { Weight loss phase: gradually } \\
\text { increase carbohydrate by } 5 \mathrm{~g} / \\
\text { day } \\
\text { Pre-maintenance phase: } \\
40-100 \mathrm{~g} / \text { day carbohydrates } \\
\text { Maintenance phase: maintain } \\
\text { ideal carbohydrate balance }{ }^{108}\end{array}$ \\
\hline Mediterranean diet & $\begin{array}{l}50-55 \% \text { low glycemic load } \\
\text { (GL) carbohydrates; } 30 \% \text { fats; } \\
\text { I5-20\% protein }\end{array}$ & $\begin{array}{l}\text { Sustained weight loss; } \\
\text { Reduction in waist } \\
\text { circumference and BMI; } \\
\text { HbAIC reduction; Reduced } \\
\text { risk of diabetes and insulin } \\
\text { resistance; Triglycerides, leptin, } \\
\text { CRP lowered; Risk of major } \\
\text { cardiovascular events reduced; } \\
\text { Increase in HDL and } \\
\text { adiponectin; Improves mental } \\
\text { health }\end{array}$ & No known limitations & $\begin{array}{l}\text { Include more of: Plant-based } \\
\text { food; Fish and other seafood; } \\
\text { Olive oil as the main dietary fat } \\
\text { source of monounsaturated } \\
\text { and polyunsaturated fatty acids } \\
\text { (MUFA and PUFA) } \\
\text { Eat in low to moderation: } \\
\text { Dairy products (mainly yogurt } \\
\text { and cheese); Wine; <4 eggs/ } \\
\text { week } \\
\text { Low frequency and amount: } \\
\text { Red meat } \\
\text { Rare: concentrated sugars or } \\
\text { honey }{ }^{49}\end{array}$ \\
\hline DASH diet & $\begin{array}{l}55 \% \text { carbohydrates; } 27 \% \text { total } \\
\text { fats; } 6 \% \text { saturated fats; } 18 \% \\
\text { protein; fiber: } 30 \mathrm{~g} \text {; } \\
\text { cholesterol: } 150 \mathrm{mg} \text {; } \\
\text { potassium: } 4,700 \mathrm{mg} \text {; calcium: } \\
\text { I, } 250 \mathrm{mg} \text {; magnesium: } 500 \mathrm{mg} \text {; } \\
\text { sodium } \square \mathrm{I} 500 \mathrm{mg}^{113}\end{array}$ & $\begin{array}{l}\text { Weight loss; Reduction in } \\
\text { waist and hip circumference, } \\
\text { hip circumference and percent } \\
\text { body fat; Improved muscle } \\
\text { strength; Reduction in HbAlc } \\
\text { and insulin resistance; } \\
\text { Improvement in T2DM; } \\
\text { Lowered blood pressure; } \\
\text { Increased HDL-cholesterol; } \\
\text { Lowered triglycerides (Evert } \\
\text { et al } 2019 \text {; Perry and Guilder } \\
2019^{115} \text { ) }\end{array}$ & No known limitations & 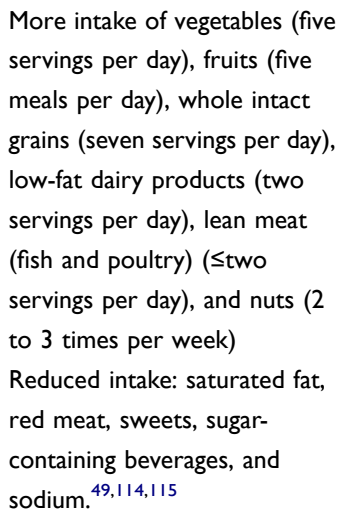 \\
\hline $\begin{array}{l}\text { Low energy diet } \\
\text { (LED)/Very low } \\
\text { energy diet } \\
\text { (VLED)/Very low } \\
\text { calorie diet } \\
\text { (VLCD) }\end{array}$ & $\begin{array}{l}\text { EASO: } 800 \mathrm{kcal} / \mathrm{day} \\
\text { VLEDs, }<800 \mathrm{kcal} / \mathrm{day} ; \text { LEDs, } \\
800-1200 \mathrm{kcal} / \mathrm{day} 49,116,117\end{array}$ & $\begin{array}{l}\text { Rapid weight reduction (3-5 } \\
\text { months), maintained up to } 4 \\
\text { years; 10-15\% of body weight } \\
\text { can be reduced; T2DM } \\
\text { remission possible in } \\
\text { overweight and obese } 49,116,117\end{array}$ & $\begin{array}{l}\text { Not suitable for children, } \\
\text { adolescents, pregnant or } \\
\text { lactating women, hepatic/renal } \\
\text { failure, heart disease, TIDM } \\
\text { and elderly } \\
\text { Possibility of non-adherence, } \\
\text { safety issues, risk of eating } \\
\text { disorders, high cost, } \\
\text { questionable long-term } \\
\text { efficacy } 49,116,117\end{array}$ & $\begin{array}{l}\text { Usually formula LED, VLED } \\
\text { and VLCD are used as partial } \\
\text { or total meal replacement; } \\
\text { Combination of } 3-4 \text { products } \\
\text { may be used per day. }{ }^{116}\end{array}$ \\
\hline
\end{tabular}

(Continued) 
Table 9 (Continued).

\begin{tabular}{|c|c|c|c|c|}
\hline Type of Diet & Definition & Reported Benefits & Reported Limitations & Comments \\
\hline $\begin{array}{l}\text { Very low calorie } \\
\text { ketogenic diet }\end{array}$ & $\begin{array}{l}\text { Type of VLCD with daily } \\
\text { energy intake }<800 \mathrm{kcal} \text { but } \\
\text { marked daily carbohydrate } \\
\text { restriction to }<30 \mathrm{~g} / \text { day ( } \\
13 \% \text { of total energy intake); fat } \\
\square 44 \% \text { and protein } \square 43 \%^{118}\end{array}$ & $\begin{array}{l}\text { Rapid weight loss, positive } \\
\text { psychology, increase } \\
\text { compliance } \\
\text { Personalized VLCKD: lean } \\
\text { mass saved, abdominal fat mass } \\
\text { reduced } \\
\text { Preservation of fatty free mass } \\
\text { which plays a key role in } \\
\text { glucose metabolism } \\
\text { Personalized VLCKD: } \\
\text { Restoration of metabolic } \\
\text { flexibility, resting energy } \\
\text { expenditure maintained, and } \\
\text { diabetes reversal }{ }^{17,27,49,118-120}\end{array}$ & $\begin{array}{l}\text { Not suitable for children, } \\
\text { adolescents, pregnant or } \\
\text { lactating women, hepatic/renal } \\
\text { failure, heart disease, TIDM } \\
\text { and elderly } \\
\text { Short-time therapy (maximum } \\
\text { I } 2 \text { weeks) }\end{array}$ & $\begin{array}{l}\text { The ketogenic period (Phases } \\
\text { I-3): } 600-800 \text { kcal/day; } \\
\text { Average length is } 8-12 \text { weeks but } \\
\text { can be prolonged until } 80-85 \% \text { of } \\
\text { the desired weight loss is } \\
\text { reached } \\
\text { Phase I: Four to six protein } \\
\text { preparations of high biological } \\
\text { value derived from green peas, } \\
\text { eggs, soy and whey are allowed } \\
\text { along with low-carbohydrate } \\
\text { vegetables. } \\
\text { Phase 2/3: Lunch or/and dinner) } \\
\text { are gradually replaced by natural } \\
\text { protein meals (meat/fish/eggs/ } \\
\text { soy). } \\
\text { Carbohydrate re-introduction } \\
\text { (Phases 4-6); The daily calorie } \\
\text { intake ranges between } 800 \text { and } \\
\text { I500 kcal/day } \\
\text { Phase 4: Foods with the lowest } \\
\text { glycemic index like fruit or dairy } \\
\text { products } \\
\text { Phase 5: Foods with moderate } \\
\text { glycemic index such as legumes } \\
\text { Phase 6: Foods with a high } \\
\text { glycemic index (bread, pasta and } \\
\text { cereals). }{ }^{118}\end{array}$ \\
\hline Vegetarian or vegan & $\begin{array}{l}\text { No or minimal animal-based } \\
\text { food }\end{array}$ & $\begin{array}{l}\text { Weight loss; HbAlc reduction; } \\
\text { Reduced diabetes risk; } \\
\text { Lowering of LDL and non- } \\
\text { HDL-cholesterol }{ }^{49}\end{array}$ & $\begin{array}{l}\text { Less acceptability and } \\
\text { adherence in non-vegetarians, } \\
\text { hence ideal only for } \\
\text { vegetarians; Vitamin } \mathrm{BI} 2 \\
\text { supplementation may be } \\
\text { required; Careful } \\
\text { micronutrient planning (zinc, } \\
\text { calcium and iron) required, } \\
\text { especially in elderly } 121,122\end{array}$ & $\begin{array}{l}\text { Vegan diet can be purely vegan } \\
\text { (no food from any animal } \\
\text { source included), lactovegan } \\
\text { (vegan diet that includes dairy } \\
\text { products), eggo-vegan (vegan } \\
\text { diet that includes eggs and the } \\
\text { Jain diet (vegan diet that does } \\
\text { not include onions, garlic, } \\
\text { roots and tubers). }{ }^{121,122}\end{array}$ \\
\hline
\end{tabular}

Abbreviations: BMI, body mass index; CAD, coronary artery disease; CRP, C-reactive proteins; DASH, Dietary Approaches to Stop Hypertension; DBP, diastolic blood pressure; EASO, The European Association for the Study of Obesity; HDL-C, high-density lipoprotein cholesterol; LDL-C, low-density lipoprotein cholesterol; SGLT2, sodium-glucose transport protein 2; TIDM; type I diabetes mellitus; T2DM, type 2 diabetes mellitus; TC, total cholesterol.

in a step-wise approach after careful assessment of the patient (Figure 5). ${ }^{53,60}$ MNT advice should be aimed at promoting weight loss without major disruption in a family's eating practices. ${ }^{60}$ MNT needs careful monitoring and adherence to achieve the desired outcomes. This can only be achieved through a collaborative effort between the patient, family members, RDs, diabetes educators, treating medical team and culinary scientists. ${ }^{53,54}$
MNT is recommended by the ADA, RSSD and Indian Council of Medical Research (ICMR) as part of routine care in diabesity. ${ }^{15,61}$ The components of MNT recommended by the ADA, RSSD and ICMR are listed in Table $10 .^{15,53,61}$ Key recommendations for components of MNT were not available from other South Asian regions. Hence, the experts involved in CoMeND studied these recommendations to 


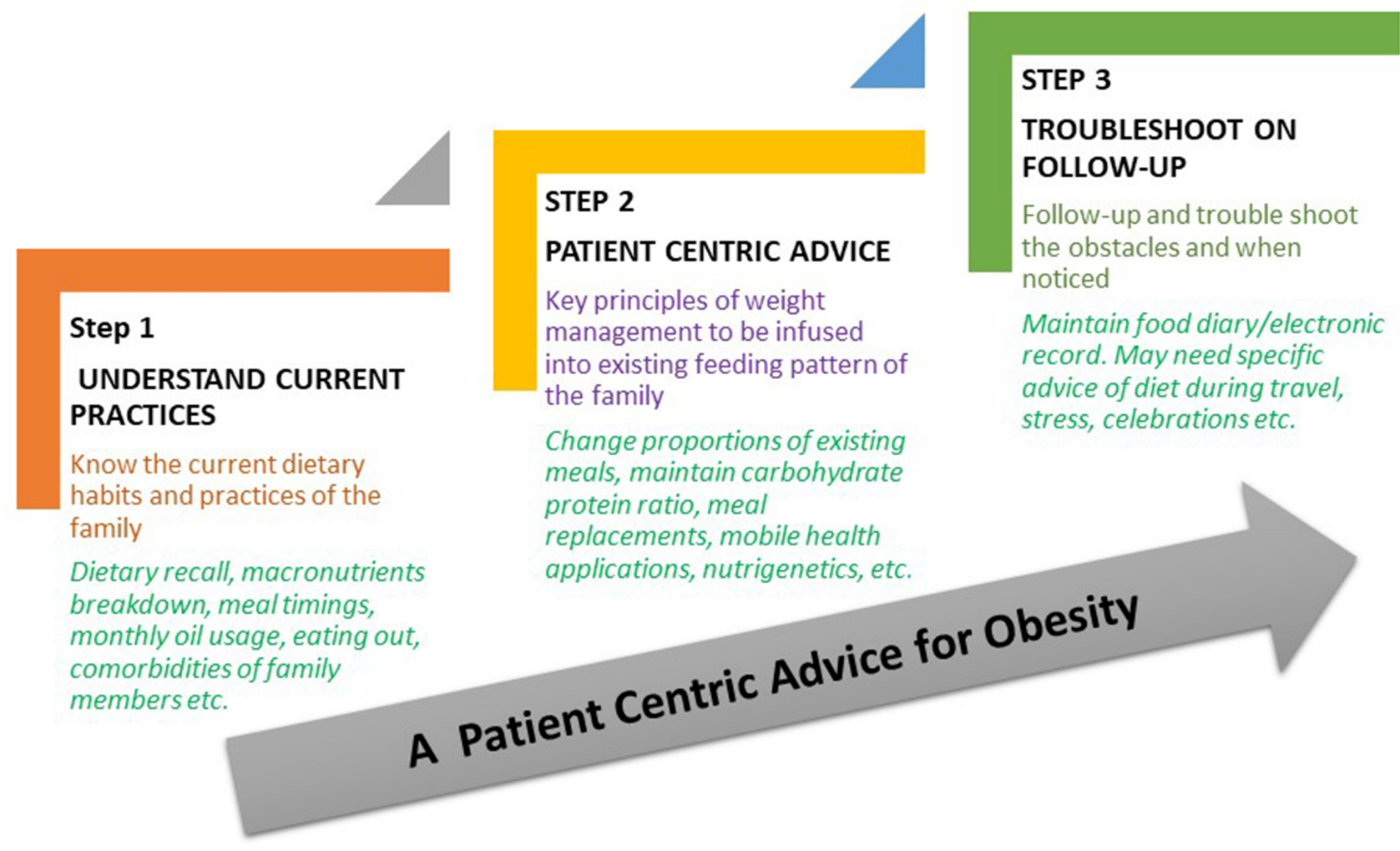

Figure 5 Step-wise approach for implementation of MNT.

Notes:Components of medical nutrition therapy. Data from Kapoor et al. ${ }^{60}$

formulate their own recommendations for South Asia. Key features are listed in Table 10.

\section{Recommendations for Medical Nutrition Therapy}

These recommendations can be divided into three main groups.

\section{Group A: General Dietary Recommendations}

1. Food portions should be reduced but not cut down drastically. The plate method can be used to control portion size of different major food groups (Figure 6).

2. The diet of a patient with diabesity in South Asia should be planned carefully, keeping in mind the country and region specific influence on culinary diversity, lifestyle and economic condition. ${ }^{11,62}$

3. Healthy dietary patterns should always be recommended. Diet education should be a part of patient counselling. ${ }^{17,63}$

4. A hypocaloric diet should be advised and individua- lized to patient's need. ${ }^{5,29}$ Appendix I gives the approximate calorific values of commonly cooked food items. This can serve as a guide for calorie planning.

5. Patients should be encouraged to maintain food diaries. These help understand food patterns, emotional eating patterns, and patients' perceptions of and behaviors towards food. ${ }^{17,63}$

\section{Group B: Nutrient and Care}

1. Carbohydrate and saturated fats should be reduced (Table 10).

2. Correct oils (PUFA and MUFA) and cooking methods (steaming, baking, shallow-fat frying, low fat cooking etc) should be advised. ${ }^{11}$

3. Unless contraindicated (eg as in kidney disease), normal protein diets or supplements should be recommended as most patients in the South Asian region consume much less protein than their RDA.

4. The goals of MNT should be monitored regularly. The frequency of monitoring may need to be 
Table 10 Components of MNT: Comparative Analysis of Recommendations by the ADA, RSSDI, ICMR and CoMeND ${ }^{15,53,61}$

\begin{tabular}{|c|c|c|c|c|}
\hline & ADA & RSSDI & ICMR & CoMeND \\
\hline \multicolumn{5}{|l|}{ Carbohydrates } \\
\hline $\begin{array}{l}\text { Recommended } \\
\text { intake }\end{array}$ & $\begin{array}{l}\text { ADA does not provide any } \\
\text { recommendations due to } \\
\text { lack of clinical evidence }\end{array}$ & $\begin{array}{l}45-65 \% \text { of total daily } \\
\text { calories (minimum intake: } \\
130 \mathrm{~g} / \text { day) }\end{array}$ & $55-60 \%$ of total daily calories & $\begin{array}{l}\text { Try to reduce current } \\
\text { carbohydrate intake by } \\
10-15 \%\end{array}$ \\
\hline $\begin{array}{l}\text { Fiber/glycemic } \\
\text { index }\end{array}$ & $\begin{array}{l}\text { High-fiber and low-glycemic } \\
\text { index diet }\end{array}$ & $\begin{array}{l}\text { High-fiber diet: increased } \\
\text { intake of soluble and } \\
\text { insoluble fibers }\end{array}$ & Intake of fiber-rich foods & $\begin{array}{l}\text { Concordant with all } \\
\text { current recommendations }\end{array}$ \\
\hline $\begin{array}{l}\text { Preferred } \\
\text { sources }\end{array}$ & $\begin{array}{l}\text { Fruits, vegetables, whole } \\
\text { grains, legumes and dairy } \\
\text { products (milk and yoghurt) }\end{array}$ & $\begin{array}{l}\text { Pulses, legumes, coarse } \\
\text { grains, sprouted grams, } \\
\text { unprocessed vegetables } \\
\text { and fruits } \\
\text { Substitution of polished } \\
\text { white rice with millets } \\
\text { and brown rice }\end{array}$ & $\begin{array}{l}\text { Cereals, mixed coarse grains, whole } \\
\text { grains (eg, ragi, oats, barley, jowar), } \\
\text { whole pulses, whole fruits, salads } \\
\text { and soybeans, leafy vegetables, } \\
\text { fenugreek seeds } \\
\text { Restricted intake of all-purpose } \\
\text { flour (maida)-based products }\end{array}$ & $\begin{array}{l}\text { Concordant with all the } \\
\text { current recommendations }\end{array}$ \\
\hline \multicolumn{5}{|l|}{ Proteins } \\
\hline $\begin{array}{l}\text { Recommended } \\
\text { intake }\end{array}$ & $\begin{array}{l}\text { Typically } 15-20 \% \text { of total } \\
\text { energy in individuals without } \\
\text { diabetic kidney disease } \\
\text { Recommended daily } \\
\text { allowance in individuals with } \\
\text { T2DM and compromised } \\
\text { renal function: of } 0.8 \mathrm{~g} / \mathrm{kg} \\
\text { body weight/day }\end{array}$ & $\begin{array}{l}10-15 \% \text { of total daily } \\
\text { calories }\end{array}$ & $10-15 \%$ of total daily calories & $\begin{array}{l}\text { Try to increase the } \\
\text { current protein intake by } \\
10 \% \text { to a maximum of I } \\
\text { gram } / \mathrm{kg} \text { body weight } / \text { day }\end{array}$ \\
\hline $\begin{array}{l}\text { Preferred } \\
\text { source }\end{array}$ & $\begin{array}{l}\text { Preferred sources: not } \\
\text { mentioned }\end{array}$ & $\begin{array}{l}\text { Preferred sources: not } \\
\text { mentioned }\end{array}$ & $\begin{array}{l}\text { Vegetable sources, low-fat milk and } \\
\text { milk products, fish and lean meat }\end{array}$ & $\begin{array}{l}\text { Concordant with ICMR } \\
\text { guidelines }\end{array}$ \\
\hline \multicolumn{5}{|l|}{ Fats } \\
\hline $\begin{array}{l}\text { Recommended } \\
\text { intake }\end{array}$ & No specified ideal intake & No specified ideal intake & $20-25 \%$ total daily calories & $\begin{array}{l}\text { Try to minimize visible fat } \\
\text { intake }\end{array}$ \\
\hline $\begin{array}{l}\text { Other } \\
\text { restrictions }\end{array}$ & $\begin{array}{l}\text { Restricted intake of } \\
\text { saturated fats: } \\
<10 \% \text { total daily calories } \\
\text { Minimal intake of trans fats } \\
\text { Restricted intake of dietary } \\
\text { cholesterol: }<300 \mathrm{mg} / \text { day }\end{array}$ & $\begin{array}{l}\text { Restricted intake of } \\
\text { saturated fats: } \\
<10 \% \text { total daily calories } \\
\text { Minimal intake of trans } \\
\text { fats } \\
\text { Restricted intake of } \\
\text { dietary cholesterol: } \\
<300 \mathrm{mg} / \text { day }\end{array}$ & $\begin{array}{l}\text { Restricted intake of saturated fats: } \\
<7 \% \text { total daily calories } \\
\text { Minimal intake of trans fats } \\
\text { ((hydrogenated vegetable fats) } \\
\text { Restricted intake of dietary } \\
\text { cholesterol: }<300 \mathrm{mg} / \text { day }\end{array}$ & $\begin{array}{l}\text { Concordant with all } \\
\text { current recommendations }\end{array}$ \\
\hline $\begin{array}{l}\text { Preferred } \\
\text { source of } \\
\text { MUFA/PUFA }\end{array}$ & Fatty fish, nuts and seeds & $\begin{array}{l}\text { Moderate intake of fish/ } \\
\text { seafood, chicken without } \\
\text { skin and red meat a as } \\
\text { a source of PUFA } \\
\text { Not recommended: } \\
\text { sunflower oil }\end{array}$ & $\begin{array}{l}\text { Groundnut, sesame, cotton seed, } \\
\text { rice bran or safflower along with } \\
\text { soybean, mustard, canola etc as } \\
\text { preferred choices for edible oils } \\
\text { containing } \\
\text { MUFA and PUFA }\end{array}$ & $\begin{array}{l}\text { Concordant with all } \\
\text { current recommendations }\end{array}$ \\
\hline
\end{tabular}

(Continued) 
Table 10 (Continued).

\begin{tabular}{|c|c|c|c|c|}
\hline & ADA & RSSDI & ICMR & CoMeND \\
\hline $\begin{array}{l}\text { Sugars and } \\
\text { sweeteners }\end{array}$ & $\begin{array}{l}\text { Reduced intake of HFCS and } \\
\text { sucrose } \\
\text { Substitute nutritive } \\
\text { sweeteners with non- } \\
\text { nutritive sweetener } \\
\text { Natural fructose/free } \\
\text { fructose from fruits }(3-4 \% \text { of } \\
\text { energy intake and not }>12) \text { is } \\
\text { permissible }\end{array}$ & $\begin{array}{l}\text { Reduced intake of refined } \\
\text { sugars } \\
\text { Moderate intake of non- } \\
\text { nutritive artificial } \\
\text { sweeteners } \\
\text { Avoid consumption of } \\
\text { HFCS }\end{array}$ & $\begin{array}{l}\text { Avoidance of sugar, honey, jaggery } \\
\text { Restricted use of artificial } \\
\text { sweeteners and avoidance in } \\
\text { pregnant/lactating women with } \\
\text { diabetes } \\
\text { Avoidance of very sweet fruits and } \\
\text { fruit } \\
\text { juices }\end{array}$ & $\begin{array}{l}\text { Concordant with all } \\
\text { current recommendations }\end{array}$ \\
\hline \multicolumn{5}{|c|}{ Micronutrients and other dietary recommendations } \\
\hline Micronutrients & $\begin{array}{l}\text { No specific } \\
\text { recommendations made }\end{array}$ & $\begin{array}{l}\text { Inclusion of } \\
\text { micronutrients } \\
\text { (chromium, alpha-lipoic } \\
\text { acid, magnesium and zinc) } \\
\text { as adjunct to standard } \\
\text { care }^{\text {b }}\end{array}$ & No specific recommendations made & $\begin{array}{l}\text { Ensure adequate } \\
\text { micronutrient intake } \\
\text { through diet and } \\
\text { exogenous sources }\end{array}$ \\
\hline Salt & $\begin{array}{l}\text { Restricted sodium intake: } \\
<2300 \mathrm{mg} / \text { day }^{c}\end{array}$ & $\begin{array}{l}\text { Restricted intake of } \\
\text { dietary salt: }<5 \mathrm{~g} / \text { day }^{\mathrm{c}}\end{array}$ & $\begin{array}{l}\text { Restricted intake of dietary salt: } \leq 6 \\
\text { g/day }\end{array}$ & $\begin{array}{l}\text { Concordant with all the } \\
\text { current } \\
\text { recommendations. Also } \\
\text { restrict non-salt sources } \\
\text { of sodium (eg ajinomoto) }\end{array}$ \\
\hline $\begin{array}{l}\text { Alcohol/ } \\
\text { tobacco }\end{array}$ & $\begin{array}{l}\text { Alcohol allowed in } \\
\text { moderation }\end{array}$ & $\begin{array}{l}\text { Avoid alcohol; cessation } \\
\text { of tobacco use }\end{array}$ & $\begin{array}{l}\text { Moderate alcohol consumption; } \\
\text { cessation of any form of tobacco use }\end{array}$ & $\begin{array}{l}\text { Concordant with ICMR } \\
\text { guidelines }\end{array}$ \\
\hline
\end{tabular}

Notes: ${ }^{a}$ Particularly in patients with established cardiovascular disease; ${ }^{b}$ insufficient evidence available; ${ }^{c}$ further restriction in patients with diabetes and hypertension. Data from these studies. ${ }^{15,53,61}$

Abbreviations: ADA, American Diabetes Association; HFCS, high-fructose corn syrup; ICMR, Indian Council of Medical Research; MUFA, mono-unsaturated fatty acids; PUFA, poly-unsaturated fatty acids; RSSDI, Research Society for the Study of Diabetes in India; T2DM, type 2 diabetes mellitus.

individualized based on patient's acceptance and adherence to MNT.

5. Any eating disorders identified should be treated as a priority through proper education, counselling and pharmacotherapy. ${ }^{17,63}$

\section{Group C: Medical Nutrition Therapy}

1. MNT should be individualized based on the Degustation Pentad (Figure 7) proposed by Dr. Kalra and colleagues. This pentad is based on a Vietnamese culinary philosophy. It suggests that an individual's meals should appeal to all five human senses (vision, smell, taste, touch, and hearing). ${ }^{54,64}$

2. MNT should be designed such that it incorporates the:

- Biomedical triplet of diet to provide the right macro-nutrient balance (protein energy) and adequate micronutrients. MNT should be medically/metabolically appropriate and yet low in glycemic index. ${ }^{54}$

- Comorbidities like dyslipidaemia, renal disease, coeliac disease, hyperuricaemia etc. ${ }^{54}$

3. MNT needs to follow the seven As of dietary choice in order to promote adherence in patients. Thus, it needs to be Appropriate and Accurate for the patient's needs, easily Absorbed, Affordable, easily Accessible, Acceptable (conform with taste preferences of the individual; have the right aroma) and Attractive (visually appealing) to that individual (Figure 8). ${ }^{53,54}$

- MNT should be affordable; crafted with locally available food items; conform with local customs, beliefs and taboos; easy to prepare; provide enough alternatives; and consider religious and social practices of the community for which it is being designed. ${ }^{54}$ 


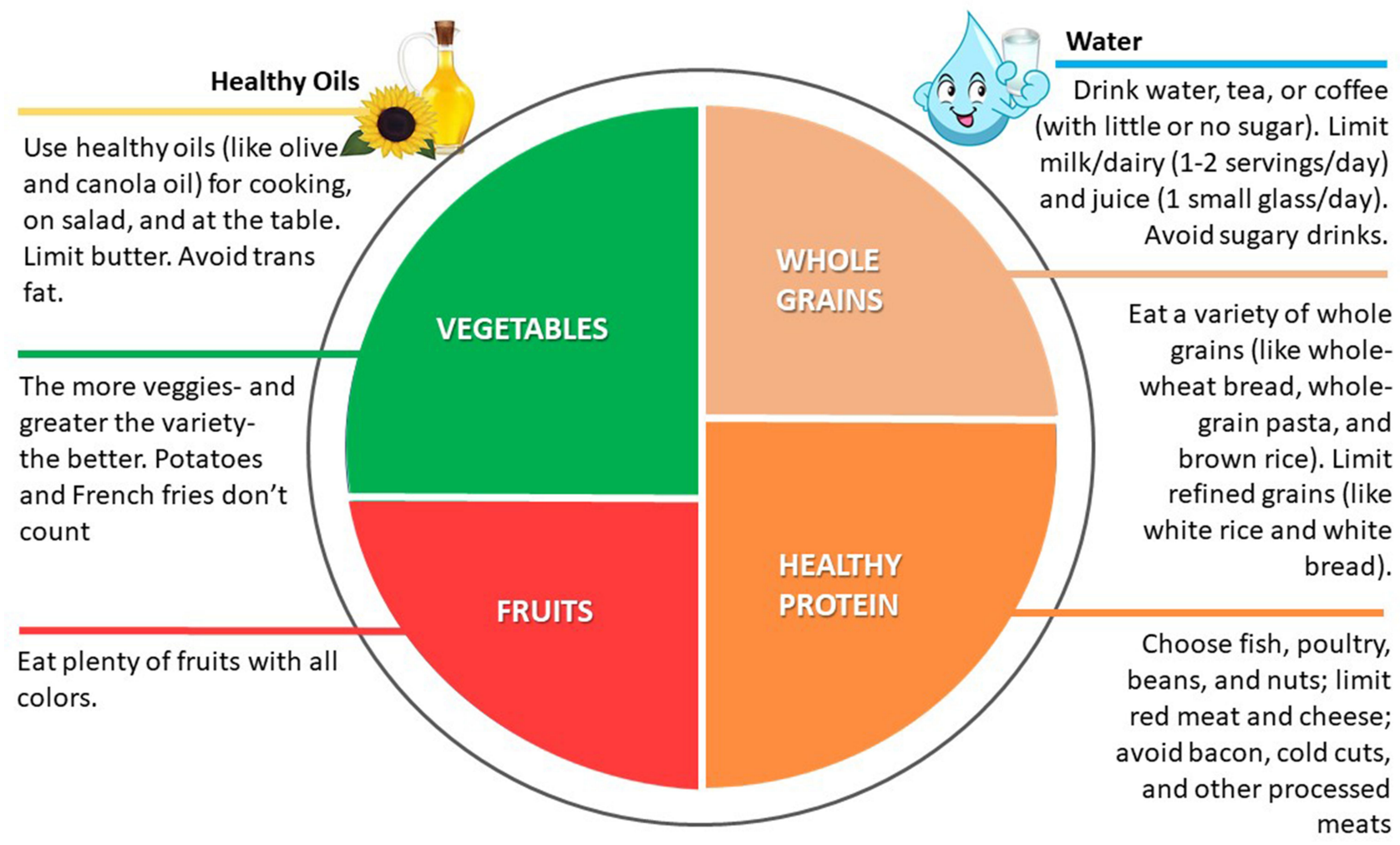

Figure 6 Plate method for meal planning.

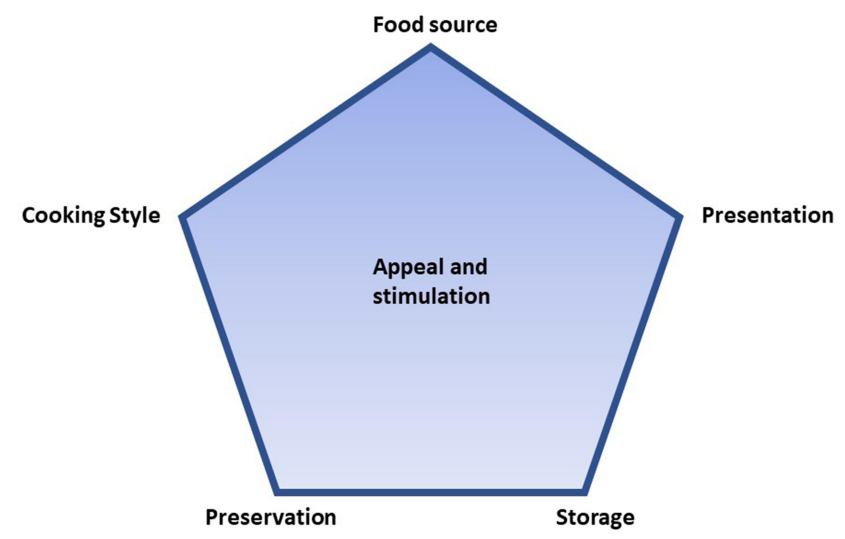

Figure 7 The culinary pentad/“Degustation Pentad”. Notes: Data from these studies. ${ }^{54,64}$

4. Formula MNT can be a:

- Meal replacement plan for patients who have a busy lifestyle or who are not willing to adhere to a strict diet regime.

- Meal replacement for individuals who have limited access to healthy cooking or who have difficulty in calculating calories.
- Meal supplement for individuals involved in exertion activities or those having chewing, swallowing or dextromotor limitations.

5. MNT should be in concordance with pharmacotherapy, so ${ }^{13}$

- A $3+3$ meal pattern is recommended with

- Intensive insulin therapy (basal bolus)

○ Sulfonylureas

- Regular snacks should be suggested for individuals

○ On pre-mixed insulin

- On human insulin

○ Having a lifestyle involving exertional physical activity.

\section{Physical Activity and Lifestyle Interventions}

Lifestyle behavior therapies are successful in reducing weight and resolving T2DM. However, the level of benefit seen varies with BMI level. In the Look AHEAD trial, patients in the bottom and top $25 \%$ lost 

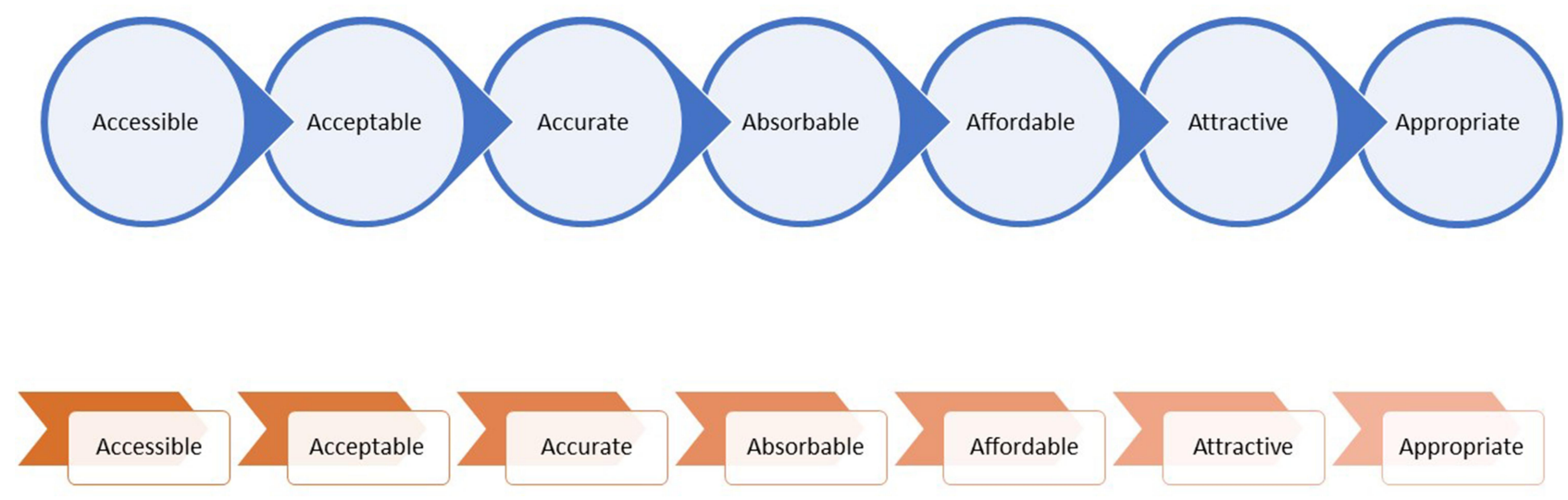

Figure 8 The seven A of MNT.

Notes: Data from these studies. ${ }^{53,54}$

$<3 \%$ of their body weight and $12 \mathrm{~kg}$ at eight years, respectively. Intensive lifestyle intervention produced better results than diabetes support and education. ${ }^{65}$

Physical activity can cause modest weight reduction. Its main importance during weight management is that it helps in preserving fat-free mass and maintaining weight. Physical activity promotes cardio-respiratory fitness and reduces cardiovascular risk. ${ }^{17}$

\section{Recommendations ${ }^{17,63}$}

1. Physical activity counselling should be an integral part of obesity management. This should include advice on building physical activity in everyday life and a supervised structured exercise program under the guidance of an expert.

2. Exercise prescription must be individualized, keeping in mind the patient's health and fitness status and ability to exercise.

3. Structured exercise levels should be gradually stepped up to levels that are safe for the patient.

4. A higher volume of physical activity is required for weight maintenance than is recommended for the general population for health maintenance.

5. Adequate protein intake should be ensured to build muscle mass during strength training.

\section{Managing Right Food Intake in a Setting of Abundance}

Urban areas in South Asia have an abundance of food. The urban population therefore needs to make the right choices in their diet when they are spoilt for choice. Many of the strategies covered in this section, however, pose challenges in lower middle income South Asian countries.

\section{Recommendations}

1. Patient education and self-restraint can help people make the right food choices. Health education and moderation in food intake should be started at school level to ensure development of healthy lifestyles and food practices for life. ${ }^{66}$

2. Restricting access to unhealthy food types may restrict their purchase and consumption and thus may help reduce weight.

3. Healthy food alternatives should be easily available at home and in the workplace.

4. It may be possible to curb obesity by providing more places for exercising and building exercise as a culture.

5. Encouraging use of smartphone apps which provide nutrition and/or exercise and fitness guidance. These apps have comprehensive nutrition databases that tell a user the nutritional content of an item after scanning the barcode, allow them to search for healthy options from restaurant menus and help them recognize food items on a plate. Smartphone sensors use machine learning and symbolic reasoning to recognize and quantify lifestyle activities of patients with diabesity and help them make more informed activity choices if necessary.

6. Proper pricing and promotion strategies need to be implemented to reduce intake of unhealthy food. These strategies include (but are not limited to) $)^{11,66-70}$
a. Establishing farmers' markets in all neighborhoods. 
Table I I What to Assess and Monitor in Patients with Diabesity

\begin{tabular}{|c|c|c|}
\hline Parameter & Assess & Monitor \\
\hline Food- and nutrition-related history & $\begin{array}{l}\text { I. Beliefs and attitudes, including food preferences } \\
\text { and motivation } \\
\text { 2. Food environment, including access to fruits and } \\
\text { vegetables } \\
\text { 3. Dietary behaviors, including eating out and screen } \\
\text { time } \\
\text { 4. Diet experience, including food allergies and diet- } \\
\text { ing history } \\
\text { 5. Medications and supplements } \\
\text { 6. Physical activity }\end{array}$ & $\begin{array}{l}\text { I. Beliefs and attitudes, including motivation } \\
\text { 2. Food environment, including access to fruits } \\
\text { and vegetables } \\
\text { 3. Dietary behaviors, including eating out and } \\
\text { screen time } \\
\text { 4. Medications and supplements } \\
\text { 5. Physical activity }\end{array}$ \\
\hline Anthropometric measurements & $\begin{array}{l}\text { I. Height, weight, body mass index } \\
\text { 2. Waist circumference } \\
\text { 3. Weight history } \\
\text { 4. Body composition }\end{array}$ & $\begin{array}{l}\text { I. Weight, body mass index } \\
\text { 2. Waist circumference } \\
\text { 3. Weight history } \\
\text { 4. Body composition }\end{array}$ \\
\hline $\begin{array}{l}\text { Biochemical data, medical tests, and } \\
\text { procedures }\end{array}$ & $\begin{array}{l}\text { I. Glucose and endocrine profile } \\
\text { 2. Lipid profile }\end{array}$ & $\begin{array}{l}\text { I. Glucose and endocrine profile } \\
\text { 2. Lipid profile }\end{array}$ \\
\hline Nutrition-focused physical findings & $\begin{array}{l}\text { I. Ability to communicate } \\
\text { 2. Affect } \\
\text { 3. Appetite } \\
\text { 4. Blood pressure } \\
\text { 5. Body language } \\
\text { 6. Heart rate }\end{array}$ & $\begin{array}{l}\text { I. Affect } \\
\text { 2. Appetite } \\
\text { 3. Blood pressure } \\
\text { 4. Body language } \\
\text { 5. Heart rate }\end{array}$ \\
\hline
\end{tabular}

Table 12 ABCDE Approach to Counselling in Diabesity

\begin{tabular}{|l|}
\multicolumn{1}{|c|}{ Counselling Methodology } \\
\hline A: Ask permission to assess \\
B: Be systematic \\
C: Communicate with empathy \\
D: De-stress the patient \\
E: Engage all stakeholders \\
\hline \multicolumn{1}{c|}{ Counselling Content } \\
\hline A: Agree upon goals/targets \\
B: Behavior change \\
C: Cycling of weight (prevention) \\
D: Diet and nutrition therapy \\
E: Exercise
\end{tabular}

b. Making subsidized fresh fruits and cooked vegetables available in schools.

c. Increasing prices of high-fat and high-sugar foods, especially in school and office cafeterias and neighborhoods (one option is to increase taxes on these). Additionally, low fat/ low sugar healthy foods can be made available at affordable prices. d. Revisiting marketing strategies involving healthy foods.

\section{Monitoring}

Patient adherence to diet and motivation to stay on diet wanes over time if the dietary recommendations are not monitored over time. ${ }^{71}$ According to the Academy of Nutrition and Dietetics, the parameters listed in Table 11 should be assessed and monitored for an effective weight management.

\section{Counselling and Motivation Need for Counselling and Motivation}

Stress is associated with overeating, which increases weight. Obesity in turn adds further stress due to development of other comorbidities and because of stigmatization. A study from Southern India on morbidly obese individuals suggested that about $30 \%$ of individuals attending an obesity clinic had psychological problems. ${ }^{72}$ This leads to a vicious cycle and diabesity management fails. Cognitive behavior therapy (CBT) can help an individual recognize and change behaviors associated with stress and overeating. It can teach an individual to manage stress well. ${ }^{17}$ 


\section{Recommendations for Counselling}

MNT and lifestyle interventions are likely to fail if patients are not kept sufficiently motivated throughout life. Hence, it is very important for physicians to understand their patients well and keep them motivated. ${ }^{73}$ The approaches mentioned in Table 12 can be used to guide counselling. However, help from a trained psychologist should be used if the physician feels that the patient needs more rigorous counselling and follow-up to follow recommended diet and lifestyle changes.

1. Diet, exercise and behavioral therapy is recommended with or without drug/surgical therapy (as applicable) and in both preventive and therapeutic settings.

2. HCPs should focus on patient's QOL and how diabesity is affecting their QOL. ${ }^{24}$

3. Addressing psychological aspects of diabesity care will help in better adherence to therapy.

4. The patient should be given the right to make decisions regarding treatment. The HCP should outline all treatment choices, their benefits and sideeffects, to the best of his/her knowledge. However, the physician should guide the treatment decision in the right direction, especially in a low literacy level patient, and where the patient's decision may cause dire consequences for health. ${ }^{25}$

5. Patient education should be built into diabesity care. This should be reinforced at diagnosis, then annually, at the time of complications/change in treatment and when there is a change in care. ${ }^{13}$

\section{Way Forward in Diabesity Management in South Asia Personalized Medicine in Diabesity: Role of Gut Microbes and Genes}

Diabesity is a chronic disease influenced by the patient's nutrient intake, food and beverage consumption, genetic background, microbiome (microbes colonizing in human beings and their genes), and omic profiles including metabolome. ${ }^{74-76}$

The gut microbiota in a patient with diabesity causes many pathological changes in energy harvest and in the modulation of free fatty acids (mainly butyrate), bile acids, lipopolysaccharides and toll-like receptors. Many other changes have been implicated in diabesity. In a nutshell, these changes result in changes in inflammation, insulin signalling and incretin production and therefore contribute to the development of diabesity. ${ }^{74,75}$

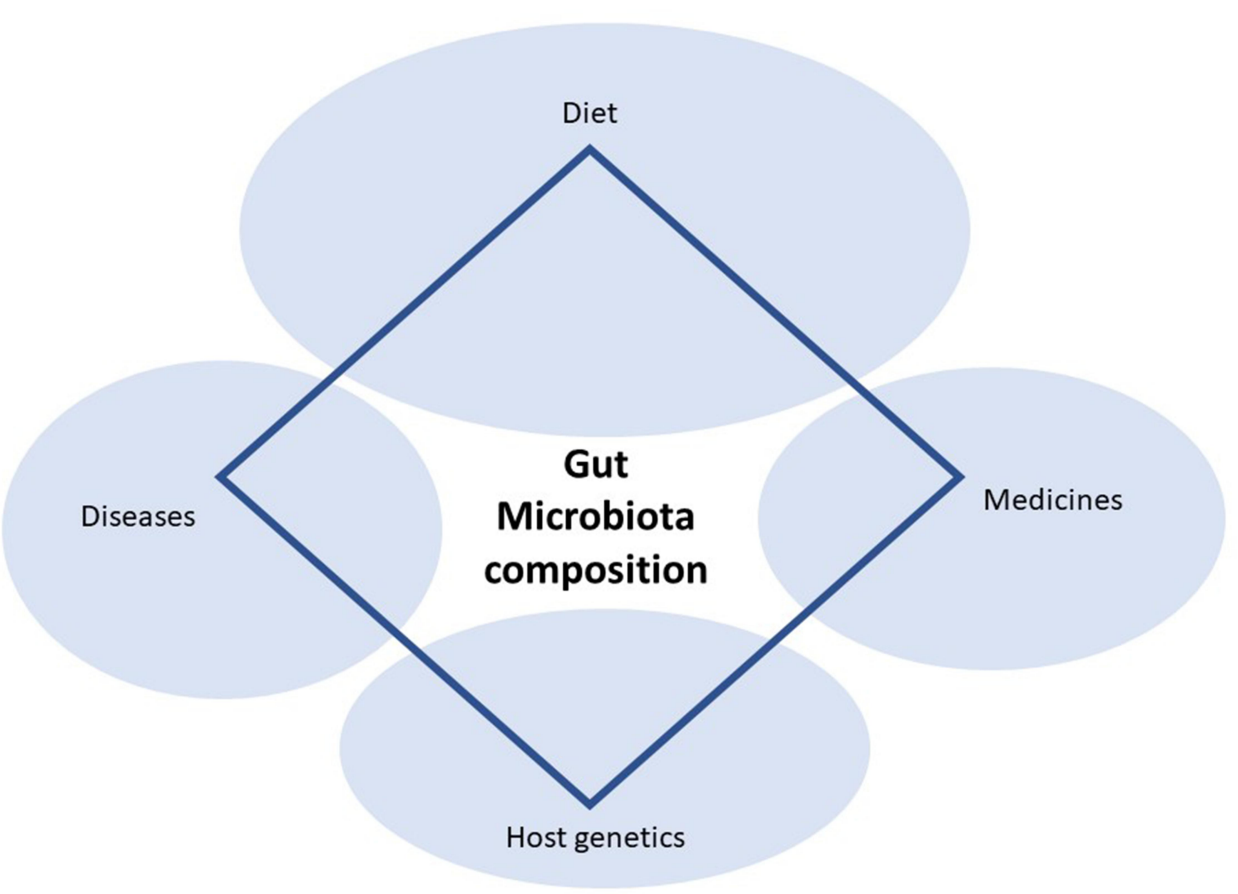

Figure 9 Diet is the main factor affecting composition of gut microbiota. 


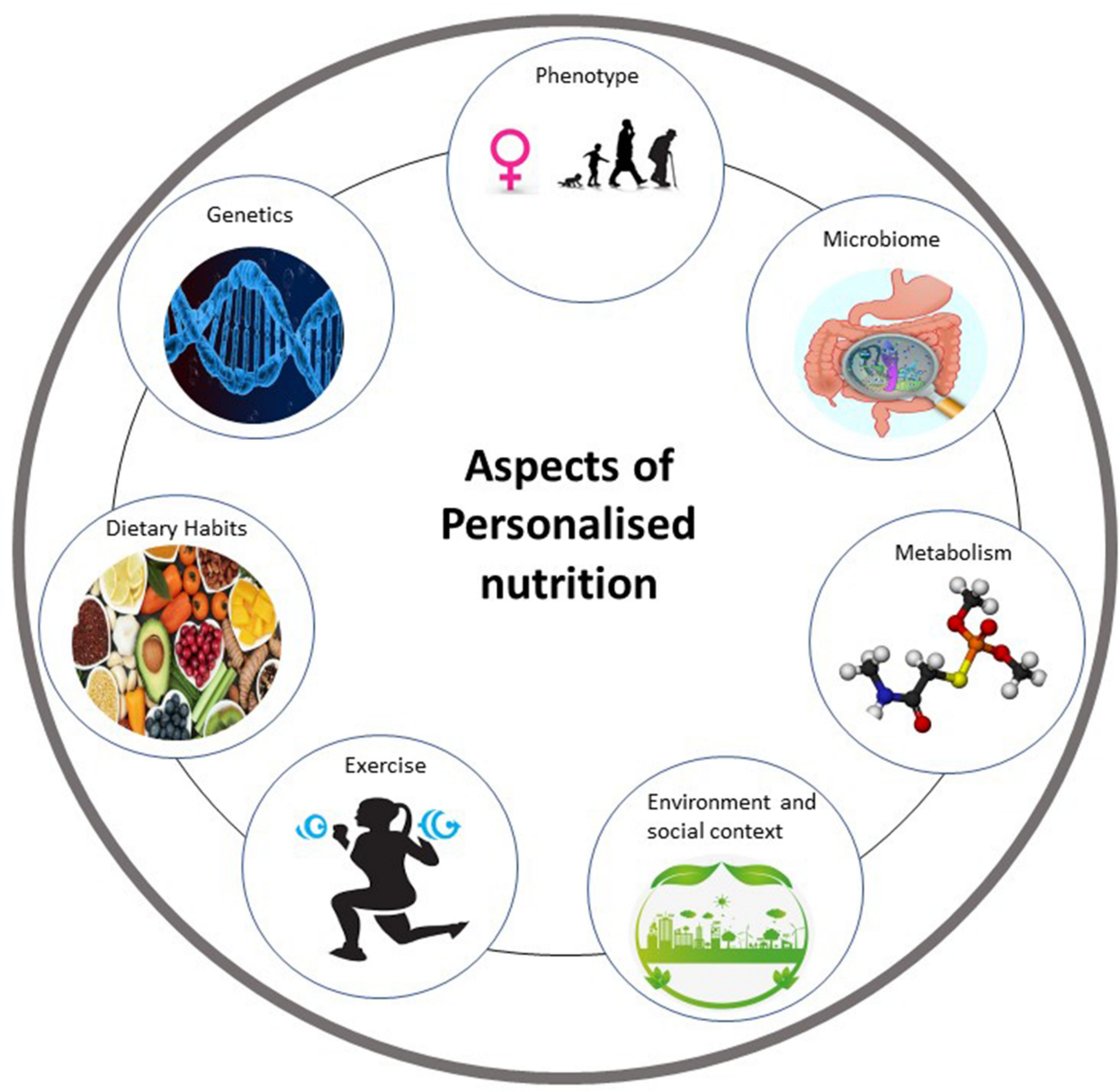

Figure 10 Different aspects of personalized nutrition.

Gut microbiota, host (patient with diabesity) and diet form an important trialogue in diabesity. ${ }^{74}$ Gut microbiota change with diet, disease, medication and other host factors. Therefore, gut microbiota in patients with diabesity differ from those in healthy individuals. Of these factors, the patient's diet plays the most important role (Figure 9).

Many genes modify the response to diet and their study can open the path to personalized medicine in diabesity. ${ }^{57,77,78}$ The POUNDS Lost study was conducted to increase understanding of this area. The study randomized 811 individuals to one of four diets: (20\% vs $40 \%$ fat and $15 \%$ vs $25 \%$ protein) to understand the genetic factors that modulate dietary response. ${ }^{79,80}$

Personalized medicine also combines many environmental factors to predict response to diet. A study showed that an algorithm integrating anthropometrics, blood parameters, dietary habits, gut microbiota and physical activity could accurately predict an individual's postprandial glycemic response to real-life meals (Figure 10). ${ }^{81,82}$
Current research in precision and/or personalized nutrition shows the benefits of individually tailoring dietary interventions (including therapeutic intervention to trigger gut microbiota with prebiotics, probiotics and synbiotics). ${ }^{74}$ However, this is a new and upcoming field. Further research, especially in the form of large Phase 3 trials, are required to understand the exact benefits of personalized medicine in diabesity.

\section{Patient/Person-Centered Care}

Since South Asia is a developing region, it is now time to introduce the Western concept of person-centered or patient-centered care. This means involving patients in their disease care, giving them the right to make treatment decisions, educating them about their disease and taking care of their psychological needs. ${ }^{13,24-26}$ The Second Diabetes Attitudes, Wishes and Needs (DAWN2) study carried out in seventeen nations, including India, shows that $26.7 \%$ of HCPs in India fail to ask their patients how diabetes affects their lives. In contrast, about $55 \%$ of patients in India 
reported that their HCPs do not ask them about their QOL with diabetes. ${ }^{24}$ Hence, concentrated efforts should be made to integrate person/patient-centered care into the diabesity care algorithm.

\section{Acknowledgment}

All named authors meet the International Committee of Medical Journal Editors (ICMJE) criteria for authorship for this manuscript, take responsibility for the integrity of the work, and have given final approval for the version to be published. The authors thank Dr. Chetan Mehndiratta, Mr. Tanmay Agrawal of Signutra Inc for execution of the study, and Dr. Kokil Mathur and Dr. Punit Srivastava of Mediception Science Pvt Ltd (www.mediception.com) for providing medical writing support in the preparation of this manuscript, funded by Signutra Inc. India.

\section{Disclosure}

The authors report no conflicts of interest in this work.

\section{References}

1. Kumar N, Puri N, Marotta F, et al. Diabesity: an epidemic with its causes, prevention and control with special focus on dietary regime. Funct Foods Health Dis. 2017;7(1):1-16. doi:10.31989/ffhd.v7i1.280

2. Bhupathiraju SN, Hu FB. Epidemiology of obesity and diabetes and their cardiovascular complications. Circ Res. 2016;118(11):17 23-1735. doi:10.1161/CIRCRESAHA.115.306825

3. IDF. IDF Diabetes Atlas 9th edition 2019. International Diabetes Federation; 2019. Available from: https://diabetesatlas.org/upload/ resources/material/20200302_133351_IDFATLAS9e-final-web.pdf. Accessed December 24, 2019.

4. Hills AP, Misra A, Gill JMR, et al. Public health and health systems: implications for the prevention and management of type 2 diabetes in south Asia. Lancet Diabetes Endocrinol. 2018;6(12):992-1002. doi:10.1016/S2213-8587(18)30203-1

5. Misra A, Jayawardena R, Anoop S. Obesity in South Asia: phenotype, morbidities, and mitigation. Curr Obes Rep. 2019;8(1):43-52. doi:10.1007/s13679-019-0328-0

6. Kapoor N, Furler J, Paul TV, Thomas N, The OB. BMI-adiposity conundrum in South Asian populations: need for further research. $J$ Biosoc Sci. 2019;51(4):619-621. doi:10.1017/S002193201900 0166

7. Kapoor N, Furler J, Paul TV, Thomas N, Oldenburg B. Normal weight obesity: an underrecognized problem in individuals of South Asian descent. Clin Ther. 2019;41(8):1638-1642. doi:10.1016/j. clinthera.2019.05.016

8. Kalra S, Unnikrishnan AG. Obesity in India: the weight of the nation. $J$ Med Nutr Nutraceuticals. 2012;1(1):37. doi:10.4103/2278019X.94634

9. Sniderman AD, Bhopal R, Prabhakaran D, Sarrafzadegan N, Tchernof A. Why might South Asians be so susceptible to central obesity and its atherogenic consequences? The adipose tissue overflow hypothesis. Int J Epidemiol. 2007;36(1):220-225. doi:10.1093/ije/ dyl245
10. Kapoor N, Chapla A, Furler J, et al. Genetics of obesity in consanguineous populations - A road map to provide novel insights in the molecular basis and management of obesity. EBioMedicine. 2019;40:33-34. doi:10.1016/j.ebiom.2019.01.004

11. Gulati S, Misra A. Abdominal obesity and type 2 diabetes in Asian Indians: dietary strategies including edible oils, cooking practices and sugar intake. Eur J Clin Nutr. 2017;71(7):850-857. doi:10.1038/ejen.2017.92

12. American Diabetes Association. 8. Obesity management for the treatment of type 2 diabetes: standards of medical care in diabetes -2019. Diabetes Care. 2019;42(Supplement1):S81-S89. doi:10. 2337/dc19-S008

13. American Diabetes Association. 5. Lifestyle management: standards of medical care in diabetes-2019. Diabetes Care. 2019;42 (Supplement1):S46-S60. doi:10.2337/dc19-S005

14. Garvey WT, Mechanick JI, Brett EM, et al. American association of clinical endocrinologists and american college of endocrinology comprehensive clinical practice guidelines for medical care of patients with obesity. Endocr Pract. 2016;22(Supplement 3):1-203. doi:10.4158/EP161365.GL

15. Bajaj S. RSSDI clinical practice recommendations for the management of type 2 diabetes mellitus 2017. Int J Diabetes Dev Ctries. 2018;38(Supp11):1-115. doi:10.1007/s13410-018-0604-7

16. Herforth A, Arimond M, Álvarez-sánchez C, Coates J, Christianson K, Muehlhoff E. A global review of food-based dietary guidelines. Adv Nutr. 2019;10(4):590-605. doi:10.1093/ advances/nmy 130

17. Yumuk V, Frühbeck G, Oppert JM, Woodward E, Toplak H. An EASO position statement on multidisciplinary obesity management in adults. Obes Facts. 2014;7(2):96-101. doi:10.1159/ 000362191

18. Lean MEJ, Leslie WS, Barnes AC, et al. Durability of a primary care-led weight-management intervention for remission of type 2 diabetes: 2-year results of the DiRECT open-label, cluster-randomised trial. Lancet Diabetes Endocrinol. 2019;7 (5):344-355. doi:10.1016/S2213-8587(19)30068-3

19. Gregg EW, Chen H, Wagenknecht LE, et al. Association of an intensive lifestyle intervention with remission of type 2 diabetes. JAMA. 2012;308(23):2489-2496. doi:10.1001/ jama.2012.67929

20. Misra A, Sharma R, Gulati S, et al. Consensus dietary guidelines for healthy living and prevention of obesity, the metabolic syndrome, diabetes, and related disorders in Asian Indians. Diabetes Technol Ther. 2011;13:683-694. doi:10.1089/dia.2010.0198

21. Misra A, Chowbey P, Makkar BM, et al. Consensus statement for diagnosis of obesity, abdominal obesity and the metabolic syndrome for Asian Indians and recommendations for physical activity, medical and surgical management. $J$ Assoc Physicians India. 2009;57:163-170.

22. Misra A, Sattar N, Tandon N, et al. Clinical management of type 2 diabetes in south Asia. Lancet Diabetes Endocrinol. 2018;6 (12):979-991. doi:10.1016/S2213-8587(18)30199-2

23. Muilwijk M, Nicolaou M, Qureshi SA, et al. Dietary and physical activity recommendations to prevent type 2 diabetes in South Asian adults: a systematic review. PLoS One. 2018;13(7): e0200681. doi:10.1371/journal.pone.0200681

24. Kalra S, Baruah MP, Sahay R. Person centered care in the second diabetes attitudes, wishes and needs (DAWN2) study: inspiration from India. Indian J Endocrinol Metab. 2014;18(1):4-6. doi:10. 4103/2230-8210.126519

25. Kalra S, Megallaa MH, Jawad F. Patient-centered care in diabetology: from eminence-based, to evidence-based, to end user-based medicine. Indian $J$ Endocrinol Metab. 2012;16 (6):871. doi:10.4103/2230-8210.102979 
26. Kalra S, Magon N, Malik S. Patient-centered care and therapeutic patient education: vedic inspiration. J Midlife Health. 2012;3 (2):59-60. doi:10.4103/0976-7800.104451

27. Romano L, Marchetti M, Gualtieri P, et al. Effects of a personalized VLCKD on body composition and resting energy expenditure in the reversal of diabetes to prevent complications. Nutrients. 2019;11(7):1526. doi:10.3390/nu11071526

28. NIN. DIETARY GUIDELINES FOR INDIANS: a Manual. National Institute of Nutrition; 2011. Available from: http://ninindia.org/ DietaryGuidelinesforNINwebsite.pdf. Accessed September 3, 2019.

29. Behl S, Misra A. Management of obesity in adult Asian Indians. Indian Heart J. 2017;69(4):539-544. doi:10.1016/j.ihj.2017.04.015

30. Kapoor N, Inian S, Thomas N. Chpater 28. Obesity with diabetes. In: A Practical Guide to Diabetes Mellitus. 8th Revised ed. Jaypee Brothers Medical Publishers; 2018. Available from: https://www.amazon.co.uk/Practical-Guide-Diabetes-Mellitus/dp/ 9352701658. Accessed April 1, 2020.

31. Kapoor N, Furler J, Paul TV, Thomas N, Oldenburg B. Ethnicityspecific cut-offs that predict co-morbidities: the way forward for optimal utility of obesity indicators. J Biosoc Sci. 2019;51 (4):624-626. doi:10.1017/S0021932019000178

32. Verma M, Rajput M, Kishore K, Asian KS. BMI criteria are better than WHO criteria in predicting hypertension: a cross-sectional study from rural India. J Family Med Prim Care. 2019;8(6):2095. doi:10.4103/jfmpc.jfmpc_257_19

33. Hsu WC, Araneta MRG, Kanaya AM, Chiang JL, Fujimoto W. BMI cut points to identify at-risk Asian Americans for type 2 diabetes screening. Diabetes Care. 2015;38(1):150-158. doi:10. 2337/dc14-2391

34. Misra A. Ethnic-specific criteria for classification of body mass index: a perspective for Asian Indians and American Diabetes Association position statement. Diabetes Technol Ther. 2015;17 (9):667-671. doi:10.1089/dia.2015.0007

35. Durrer Schutz D, Busetto L, Dicker D, et al. European practical and patient-centred guidelines for adult obesity management in primary care. Obes Facts. 2019;12(1):40-66. doi:10.1159/000496183

36. Kapoor N, Lotfaliany M, Sathish T, et al. Obesity indicators that best predict type 2 diabetes in an Indian population: insights from the Kerala diabetes prevention program. J Nutr Sci. 2020;9. doi: $10.1017 /$ jns. 2020.8

37. Weir CB, Jan A. BMI classification percentile and cut off points. In: StatPearls. StatPearls Publishing; 2020. Available from: http:// www.ncbi.nlm.nih.gov/books/NBK541070/. Accessed February 16, 2020.

38. Thomas N, Kapoor N, Velavan J, Vasan KS. A Practical Guide to Diabetes Mellitus. 8th ed. Jaypee Brothers Medical Pub; 2018.

39. Okorodudu DO, Jumean MF, Montori VM, et al. Diagnostic performance of body mass index to identify obesity as defined by body adiposity: a systematic review and meta-analysis. Int J Obes. 2010;34(5):791-799. doi:10.1038/ijo.2010.5

40. Després J-P. Body fat distribution and risk of cardiovascular disease: an update. Circulation. 2012;126(10):1301-1313. doi:10.1161/CIRCULATIONAHA.111.067264

41. Matsuzawa Y, Funahashi T, Nakamura T. The concept of metabolic syndrome: contribution of visceral fat accumulation and its molecular mechanism. $J$ Atheroscler Thromb. 2011;18(8):6 29-639. doi:10.5551/jat.7922

42. Sahakyan KR, Somers VK, Rodriguez-Escudero JP, et al. Normal-weight central obesity: implications for total and cardiovascular mortality. Ann Intern Med. 2015;163(11):827-835. doi:10.7326/M14-2525

43. Berstad P, Randby A, Seim Ekeland G, Ulveland H, Omland T, Almendingen K. Body fat and fat-free mass measured by bioelectric impedance spectroscopy and dual-energy X-ray absorptiometry in obese and non-obese adults. Br J Nutr. 2012;107 (8):1192-1200. doi:10.1017/S000711451100417X
44. Kalra S, Kapoor N, Kota S, Das S. Person-centred obesity care techniques, thresholds, tools and targets. Eur Endocrinol. 2020;16 (1):11. doi:10.17925/EE.2020.16.1.11

45. Brehm BJ, Seeley RJ, Daniels SR, D’Alessio DA. A randomized trial comparing a very low carbohydrate diet and a calorie-restricted low fat diet on body weight and cardiovascular risk factors in healthy women. $J$ Clin Endocrinol Metab. 2003;88 (4):1617-1623. doi:10.1210/jc.2002-021480

46. Kalra S, Kalra B, Sahay R. Indications for formula medical nutrition therapy in diabetes. J Pak Med Assoc. 2019;69 (6):908-910.

47. Cederholm T, Barazzoni R, Austin P, et al. ESPEN guidelines on definitions and terminology of clinical nutrition. Clin Nutr. 2017;36(1):49-64. doi:10.1016/j.clnu.2016.09.004

48. Freijer K, Volger S, Pitter JG, et al. Medical nutrition terminology and regulations in the United States and Europe-a scoping review: report of the ISPOR nutrition economics special interest group. Value Health. 2019;22(1):1-12. doi:10.1016/j. jval.2018.07.879

49. Evert AB, Dennison M, Gardner CD, et al. Nutrition therapy for adults with diabetes or prediabetes: a consensus report. Diabetes Care. 2019;42(5):731-754. doi:10.2337/dci19-0014

50. Raynor HA, Champagne CM. Position of the academy of nutrition and dietetics: interventions for the treatment of overweight and obesity in adults. J Acad Nutr Diet. 2016;116(1):129-147. doi:10.1016/j.jand.2015.10.031

51. Hernandez TL, Brand-Miller JC. Nutrition therapy in gestational diabetes mellitus: time to move forward. Diabetes Care. 2018;41 (7):1343-1345. doi:10.2337/dci18-0014

52. Kalra S, Joshi S, Baruah M. Medical nutrition therapy for diabetes: the challenge in India. $J$ Med Nutr Nutraceuticals. 2012;1 (1):3. doi:10.4103/2278-019X.94626

53. Viswanathan V, Krishnan D, Kalra S, et al. Insights on medical nutrition therapy for type 2 diabetes mellitus: an Indian perspective. $A d v$ Ther. 2019;36(3):520-547. doi:10.1007/s123 25-019-0872-8

54. Kalra S, Priya G, Chaudhary S, Saboo B. The triad and pentads of medical nutrition therapy in diabetes. $J$ Pak Med Assoc. 2019;69:277-279.

55. Assaf-Balut C, de la Torre NG, Durán A, et al. Medical nutrition therapy for gestational diabetes mellitus based on Mediterranean diet principles: a subanalysis of the St Carlos GDM prevention study. BMJ Open Diabetes Res Care. 2018;6(1):e000550. doi:10.1136/bmjdrc-2018-000550

56. Shai I, Schwarzfuchs D, Henkin Y, et al. Weight loss with a low-carbohydrate, Mediterranean, or low-fat diet. $N$ Engl $J$ Med. 2008;359(3):229-241. doi:10.1056/NEJMoa0708681

57. Bray GA, Heisel WE, Afshin A, et al. The science of obesity management: an endocrine society scientific statement. Endocr Rev. 2018;39(2):79-132. doi:10.1210/er.2017-00253

58. Sacks FM, Bray GA, Carey VJ, et al. Comparison of weight-loss diets with different compositions of fat, protein, and carbohydrates. $N$ Engl J Med. 2009;360(9):859-873. doi:10. 1056/NEJMoa0804748

59. Daly A, Michael P, Johnson EQ, Harrington CC, Patrick S, Bender T. Diabetes white paper: defining the delivery of nutrition services in Medicare medical nutrition therapy vs Medicare diabetes self-management training programs. $J \mathrm{Am}$ Diet Assoc. 2009;109(3):528-539. doi:10.1016/j. jada.2008.11.004

60. Kapoor N. Medical nutrition therapy in obesity - a person-centred approach. touchENDOCRINOLOGY; 2020. Available from: https://www.touchendocrinology.com/insight/medical-nutritiontherapy-in-obesity-a-person-centred-approach/. Accessed April $16,2020$. 
61. American Diabetes Association. 16. Diabetes advocacy: standards of medical care in diabetes-2019. Diabetes Care. 2019;42 (Supplement1):S182-S183. doi:10.2337/dc19-S016

62. Ley SH, Hamdy O, Mohan V, Hu FB. Prevention and management of type 2 diabetes: dietary components and nutritional strategies. Lancet. 2014;383(9933):1999-2007. doi:10.1016/ S0140-6736(14)60613-9

63. Tsigos C, Hainer V, Basdevant A, et al. Management of obesity in adults: European clinical practice guidelines. Obes Facts. 2008;1 (2):106-116. doi:10.1159/000126822

64. Kalra S, Choubey N. Involving culinary science as part of the diabetes care team. J Pak Med Assoc. 2017;67:1795-1796.

65. Courcoulas AP, Christian NJ, Belle SH, et al. Weight change and health outcomes at 3 years after bariatric surgery among individuals with severe obesity. JAMA. 2013;310(22):2416-2425. doi:10.1001/jama.2013.280928

66. Nga VT, Dung VNT, Chu D-T, et al. School education and childhood obesity: a systemic review. Diabetes Metab Syndr. 2019;13 (4):2495-2501. doi:10.1016/j.dsx.2019.07.014

67. Malhotra A, Schofield G, Lustig RH. The science against sugar, alone, is insufficient in tackling the obesity and type 2 diabetes crises - we must also overcome opposition from vested interests. J Australasian Coll Nutr Env Med. 2019;38(1):4.

68. Khandelwal S, Reddy KS. Eliciting a policy response for the rising epidemic of overweight-obesity in India. Obes Rev. 2013;14(S2):114-125. doi:10.1111/obr.12097

69. Glanz K, Hoelscher D. Increasing fruit and vegetable intake by changing environments, policy and pricing: restaurant-based research, strategies, and recommendations. Prev Med. 2004;39 (Suppl 2):S88-S93. doi:10.1016/j.ypmed.2004.03.002

70. Glanz K, Yaroch AL. Strategies for increasing fruit and vegetable intake in grocery stores and communities: policy, pricing, and environmental change. Prev Med. 2004;39(Suppl 2):S75-S80. doi:10.1016/j.ypmed.2004.01.004

71. Jospe MR, Roy M, Brown RC, et al. Intermittent fasting, Paleolithic, or Mediterranean diets in the real world: exploratory secondary analyses of a weight-loss trial that included choice of diet and exercise. Am J Clin Nutr. 2019. doi:10.1093/ajen/nqz330

72. Jiwanmall SA, Kattula D, Nandyal MB, et al. Psychiatric burden in the morbidly obese in multidisciplinary bariatric clinic in South India. Indian J Psychol Med. 2018;40(2):129-133. doi:10.4103/ IJPSYM.IJPSYM_187_17

73. Kahan S, Manson JE. Obesity treatment, beyond the guidelines: practical suggestions for clinical practice. JAMA. 2019;321 (14):1349-1350. doi:10.1001/jama.2019.2352

74. Lazar V, Ditu L-M, Pircalabioru GG, et al. Gut microbiota, host organism, and diet trialogue in diabetes and obesity. Front Nutr. 2019;6. doi:10.3389/fnut.2019.00021

75. Harsch IA, Konturek PC. The role of gut microbiota in obesity and type 2 and type 1 diabetes mellitus: new insights into "old" diseases. Med Sci. 2018;6(2):32. doi:10.3390/medsci6020032

76. Baothman OA, Zamzami MA, Taher I, Abubaker J, Abu-Farha $\mathrm{M}$. The role of gut microbiota in the development of obesity and diabetes. Lipids Health Dis. 2016;15(1):108. doi:10.1186/s12944016-0278-4

77. Mohan V, Das AK, Mukherjee JJ, Seshadri K, Jha S, Kalra S. From Individualized to personalized medicine in diabetes: an expert overview. J Assoc Physicians India. 2019;67(9):78-82.

78. Rajadhyaksha V. Managing diabetes patients in India: is the future more bitter or less sweet? Perspect Clin Res. 2018;9(1):1. doi:10.4103/picr.PICR_161_17

79. Huang T, Zheng Y, Hruby A, et al. Dietary protein modifies the effect of the MC4R genotype on 2-year changes in appetite and food craving: the POUNDS lost trial. J Nutr. 2017;147 (3):439-444. doi:10.3945/jn.116.242958
80. Hamman RF, Wing RR, Edelstein SL, et al. Effect of weight loss with lifestyle intervention on risk of diabetes. Diabetes Care. 2006;29(9):2102-2107. doi:10.2337/dc06-0560

81. Zeevi D, Korem T, Zmora N, et al. Personalized nutrition by prediction of glycemic responses. Cell. 2015;163(5):1079-1094. doi:10.1016/j.cell.2015.11.001

82. Drabsch T, Holzapfel C, Scientific A. Perspective of personalised gene-based dietary recommendations for weight management. Nutrients. 2019;11(3):617. doi:10.3390/nu11030617

83. Shannawaz M, Arokiasamy P. Overweight/obesity: an emerging epidemic in India. J Clin Diagn Res. 2018;12(11). doi:10.7860/ JCDR/2018/37014.12201

84. Kumar A, Kalra S, Unnikrishnan AG. Metabolic state of the nation: results of the national family health survey-4. Indian $J$ Endocrinol Metab. 2016;20(4):429. doi:10.4103/22308210.183453

85. Ardahan M, Konal E. The prevalence of hypertension and obesity and effective factors: a cross-sectional bazaar study. J Pak Med Assoc. 2019;69(7):1018-1021.

86. Tanwi TS, Chakrabarty S, Hasanuzzaman S, Saltmarsh S, Winn S. Socioeconomic correlates of overweight and obesity among ever-married urban women in Bangladesh. BMC Public Health. 2019;19(1):842. doi:10.1186/s12889-019-7221-3

87. Latt TS, Ko K, Aye TT, Thidar A, Khin EEA. Summary of the Myanmar clinical practice guidelines for the management of obesity. J ASEAN Fed Endocr Soc. 2014;26(2):105.

88. Somasundaram N, Ranathunga I, Gunawardana K, et al. High prevalence of overweight/obesity in urban Sri Lanka: findings from the Colombo urban study. J Diabetes Res. 2019;2016. doi:10.1155/2019/2046428

89. Saeed KMI. Pattern of adult obesity in Kabul capital of Afghanistan: a cross sectional study using who stepwise tool. IOSR J Pharm. 2016;6(11):89-96.

90. Saeed KMI, Rasooly MH, Nejaby MJ. Profile of risk factors for noncommunicable diseases in major cities of Afghanistan: WHO STEPwise approach. East Mediterr Health J. 2020;26 (04):388-399. doi:10.26719/emhj.20.005

91. Rawal LB, Kanda K, Mahumud RA, et al. Prevalence of underweight, overweight and obesity and their associated risk factors in Nepalese adults: data from a Nationwide Survey, 2016. PLoS One. 2018;13(11):e0205912. doi:10.1371/journal.pone.0205912

92. World Health Organization. World Health Organization - diabetes country profiles-Bhutan. 2016. Available from: https://www.who. int/diabetes/country-profiles/btn_en.pdf. Accessed April 1, 2020.

93. Sithey G, Li M, Thow AM. Strengthening non-communicable disease policy with lessons from Bhutan: linking gross national happiness and health policy action. $J$ Public Health Policy. 2018;39(3):327-342. doi:10.1057/s41271-018-0135-y

94. Sithey G, Thow AM, Sharma J, Lhazin K, Li M. Taking action on prevention and control of noncommunicable diseases in Bhutan by strengthening gross national happiness. Bhutan Health J. 2018;4(2):46-50. doi:10.47811/bhj.69

95. Canning KL, Brown RE, Wharton S, Sharma AM, Kuk JL. Edmonton obesity staging system prevalence and association with weight loss in a publicly funded referral-based obesity clinic. J Obes. 2015;2015:1-7. doi:10.1155/2015/619734

96. Sharma AM, Kushner RF. A proposed clinical staging system for obesity. Int J Obes. 2009;33(3):289-295. doi:10.1038/ijo.2009.2

97. Daniel S, Soleymani T, Garvey WT. A complications-based clinical staging of obesity to guide treatment modality and intensity. Curr Opin Endocrinol Diabetes Obes. 2013;20(5):377-388. doi:10.1097/01.med.0000433067.01671.f5

98. Oh R, Uppaluri KR. Low carbohydrate diet. In: StatPearls. StatPearls Publishing; 2019. Available from: http://www.ncbi. nlm.nih.gov/books/NBK537084/. Accessed January 13, 2020. 
99. Davis JN, Alexander KE, Ventura EE, Toledo-Corral CM, Goran MI. Inverse relation between dietary fiber intake and visceral adiposity in overweight Latino youth. Am J Clin Nutr. 2009;90(5):1160-1166. doi:10.3945/ajen.2009.28133

100. Goldstein T, Kark JD, Berry EM, Adler B, Ziv E, Raz I. The effect of a low carbohydrate energy-unrestricted diet on weight loss in obese type 2 diabetes patients - a randomized controlled trial. E Spen Eur E J Clin Nutr Metab. 2011;6(4):e178-e186. doi:10.1016/j.eclnm.2011.04.003

101. Meng Y, Bai H, Wang S, Li Z, Wang Q, Chen L. Efficacy of low carbohydrate diet for type 2 diabetes mellitus management: a systematic review and meta-analysis of randomized controlled trials. Diabetes Res Clin Pract. 2017;131:124-131. doi:10.1016/j. diabres.2017.07.006

102. Bueno NB, De melo ISV, de Oliveira SL, da Rocha Ataide T. Verylow-carbohydrate ketogenic diet v. low-fat diet for long-term weight loss: a meta-analysis of randomised controlled trials. $\mathrm{Br} J$ Nutr. 2013;110(7):1178-1187. doi:10.1017/S0007114513000548

103. Yabe D, Iwasaki M, Kuwata H, et al. Sodium-glucose co-transporter-2 inhibitor use and dietary carbohydrate intake in Japanese individuals with type 2 diabetes: a randomized, open-label, 3-arm parallel comparative, exploratory study. Diabetes Obes Metab. 2017;19(5):739-743. doi:10.1111/dom.12848

104. Davis NJ, Tomuta N, Schechter C, et al. Comparative study of the effects of a 1-year dietary intervention of a low-carbohydrate diet versus a low-fat diet on weight and glycemic control in type 2 diabetes. Diabetes Care. 2009;32(7):1147-1152. doi:10.2337/ dc08-2108

105. Murphy EA, Jenkins TJ. A ketogenic diet for reducing obesity and maintaining capacity for physical activity: hype or hope? Curr Opin Clin Nutr Metab Care. 2019;22(4):314-319. doi:10.1097/MCO.0000000000000572

106. Gupta L, Khandelwal D, Lal PR, Kalra S, Dutta D. Palaeolithic diet in diabesity and endocrinopathies - a Vegan's perspective. Eur Endocrinol. 2019;15(2):77-82. doi:10.17925/EE.2019.15.2.77

107. Obert J, Pearlman M, Obert L, Chapin S. Popular weight loss strategies: a review of four weight loss techniques. Curr Gastroenterol Rep. 2017;19(12):61. doi:10.1007/s11894-017-0603-8

108. Kuchkuntla AR, Limketkai B, Nanda S, Hurt RT, Mundi MS. Fad diets: hype or hope? Curr Nutr Rep. 2018;7(4):310-323. doi:10.1007/s13668-018-0242-1

109. Serra-Majem L, Román-Viñas B, Sanchez-Villegas A, GuaschFerré M, Corella D, La Vecchia C. Benefits of the Mediterranean diet: epidemiological and molecular aspects. Mol Aspects Med. 2019;67:1-55. doi:10.1016/j.mam.2019.06.001

110. Salas-Salvadó J, Díaz-López A, Ruiz-Canela M, et al. Effect of a lifestyle intervention program with energy-restricted mediterranean diet and exercise on weight loss and cardiovascular risk factors: one-year results of the PREDIMED-plus trial. Diabetes Care. 2019;42(5):777-788. doi:10.2337/dc180836
111. Baptiste DD The impact of mediterranean diet on adult obesity: a quality improvement. 2019. Available from: https://mospace.umsys tem.edu/xmlui/handle/10355/67981. Accessed January 13, 2020.

112. Eder P, Niezgódka A, Krela-Kaźmierczak I, Stawczyk-Eder K, Banasik E, Dobrowolska A. Dietary support in elderly patients with inflammatory bowel disease. Nutrients. 2019;11(6):1421. doi:10.3390/nu11061421

113. Campbell AP. DASH eating plan: an eating pattern for diabetes management. Diabetes Spectr. 2017;30(2):76-81. doi:10.2337/ ds $16-0084$

114. Perry C, Guilder GV. Positive improvements on body composition and muscle strength in older adults consuming the dietary approaches to stop hypertension diet containing beef (OR18-0119). Curr Dev Nutr. 2019;3(Supplement_1):nzz028-OR18. doi:10.1093/cdn/nzz028.OR18-01-19

115. Perry CA, Guilder GPV, Kauffman A and Hossain M. A CalorieRestricted DASH Diet Reduces Body Fat and Maintains Muscle Strength in Obese Older Adults. Nutrients. 2019;12(1):102

116. Brown A, Leeds AR. Very low-energy and low-energy formula diets: effects on weight loss, obesity co-morbidities and type 2 diabetes remission - an update on the evidence for their use in clinical practice. Nutr Bull. 2019;44(1):7-24. doi:10.1111/ nbu. 12372

117. Bhatt AA, Choudhari PK, Mahajan RR, et al. Effect of a low-calorie diet on restoration of normoglycemia in obese subjects with type 2 diabetes. Indian J Endocrinol Metab. 2017;21 (5):776. doi:10.4103/ijem.IJEM_206_17

118. Caprio M, Infante M, Moriconi E, et al. Very-low-calorie ketogenic diet (VLCKD) in the management of metabolic diseases: systematic review and consensus statement from the Italian Society of Endocrinology (SIE). J Endocrinol Invest. 2019;42 (11):1365-1386. doi:10.1007/s40618-019-01061-2

119. Muscogiuri G, Barrea L, Laudisio D, et al. The management of very low-calorie ketogenic diet in obesity outpatient clinic: a practical guide. J Transl Med. 2019;17(1):356. doi:10.1186/ s12967-019-2104-z

120. Luat AF, Coyle L, Kamat D. The ketogenic diet: a practical guide for pediatricians. Pediatr Ann. 2016;45(12):e446-e450. doi:10.3928/19382359-20161109-01

121. Agrawal S, Millett CJ, Dhillon PK, Subramanian S, Ebrahim S. Type of vegetarian diet, obesity and diabetes in adult Indian population. Nutr J. 2014;13(1):89. doi:10.1186/1475-2891-13-89

122. Turner-McGrievy G, Mandes T, Crimarco A. A plant-based diet for overweight and obesity prevention and treatment. J Geriatr Cardiol. 2017;14(5):369-374. doi:10.11909/j.issn.1671-5411.20 17.05.002

Diabetes, Metabolic Syndrome and Obesity: Targets and Therapy

\section{Publish your work in this journal}

Diabetes, Metabolic Syndrome and Obesity: Targets and Therapy is an international, peer-reviewed open-access journal committed to the rapid publication of the latest laboratory and clinical findings in the fields of diabetes, metabolic syndrome and obesity research. Original research, review, case reports, hypothesis formation, expert opinion and commentaries are all considered for publication. The manuscript management system is completely online and includes a very quick and fair peer-review system, which is all easy to use. Visit http://www.dovepress.com/testimonials.php to read real quotes from published authors. 